I NTER NATIONAL MONETARY FUND
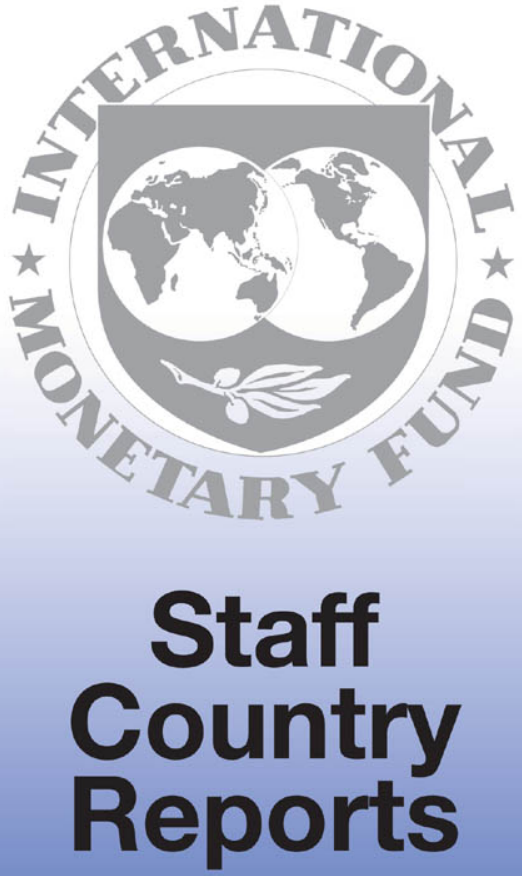


\section{Mexico: Arrangement Under the Flexible Credit Line and Cancellation of the Current Arrangement-Staff Report; Staff Supplement; and Press Release on the Executive Board Discussion}

In the context of the arrangement for Mexico under the Flexible Credit Line and the cancellation of the current arrangement, the following documents have been released and are included in this package:

- $\quad$ The staff report on the arrangement for Mexico under the Flexible Credit Line and cancellation of the current arrangement, prepared by a staff team of the IMF, based on information available as of December 23, 2010. The views expressed in the staff report are those of the staff team and do not necessarily reflect the views of the Executive Board of the IMF.

- A staff supplement of December 29, 2010, on the assessment of the impact of the proposed flexible credit line arrangement on the Fund's finances and liquidity position.

- $\quad$ A Press Release summarizing the views of the Executive Board as expressed during its January 10, 2011 discussion of the staff report that completed the request.

The policy of publication of staff reports and other documents allows for the deletion of marketsensitive information.

Copies of this report are available to the public from

International Monetary Fund • Publication Services

$70019^{\text {th }}$ Street, N.W. • Washington, D.C. 20431

Telephone: (202) 623-7430 • Telefax: (202) 623-7201

E-mail: publications@imf.org Internet: http://www.imf.org

Price: $\$ 18.00$ a copy

\section{International Monetary Fund \\ Washington, D.C.}


INTERNATIONAL MONETARY FUND

MEXICO

\title{
Arrangement Under the Flexible Credit Line and Cancellation of the Current Arrangement
}

\author{
Prepared by the Western Hemisphere Department \\ (In consultation with other departments)
}

Approved by David J. Robinson and Aasim Husain

December 23, 2010

\section{Summary}

- $\quad$ Background. Mexico was hard hit by the global financial crisis. Growth fell sharply in 2009 and financial markets came under severe pressure. But strong policies and frameworks have helped maintain stability. External contingent financing - with FCLs from the Fund and the U.S. Federal Reserve swap facility-has also helped.

- Outlook. Mexico is in the midst of a cyclical bounce-back, which is expected to moderate going forward. Inflation is expected to converge towards the 3 percent target (with a variability interval of $-/+1$ percent) by mid-2011 and the authorities have continued taking proactive steps to tackle medium-term challenges, including through an important tax reform in 2010 .

- $\quad$ Risks. Global risks have increased since approval of the current FCL arrangement while room for policy maneuver at the international level to address further shocks is much diminished.

- $\quad \boldsymbol{F C L}$. In this context, the authorities would like to seek a two-year precautionary FCL arrangement in an amount equivalent to SDR 47.292 billion (1,500 percent of quota), and cancel the current arrangement approved on March 25, 2010. They believe that the enhanced access and tenor for FCL arrangements - made possible by the recent Fund facilities reform - presents more suitable insurance for the risks facing Mexico at the current juncture. They have also commented that the enhanced FCL acts as an increasingly closer substitute for self-insuring against external risks, and will be a consideration in their reserves strategy going forward. The staff assesses that Mexico meets the qualification criteria for access to FCL resources, and recommends approval of the arrangement.

- $\quad$ Fund liquidity and process. The proposed commitment would have a very substantial, but manageable impact on the Fund's liquidity. An informal meeting to consult the Executive Board on a possible FCL arrangement for Mexico was held on December 13, 2010.

- $\quad$ Team. This report was prepared by Enrique Flores, Vikram Haksar, Man-Keung Tang, Francisco Vazquez-Ahued (all WHD), Kai Guo (SPR), Patrick Imam (MCM), and Pablo Lopez-Murphy (FAD). 


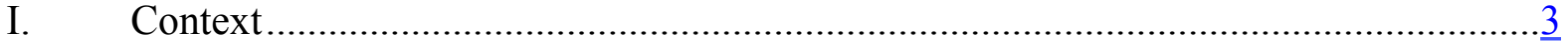

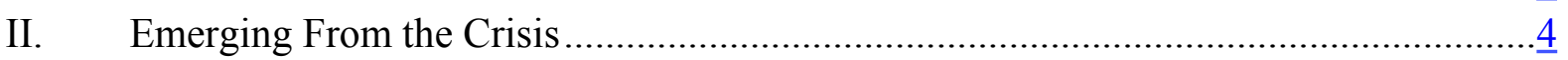

III. Outlook and Near-Term Policies .......................................................................

IV. Role of the Flexible Credit Line ........................................................................ 11

V. Impact on Fund Finances, Risks, and Safeguards..............................................22

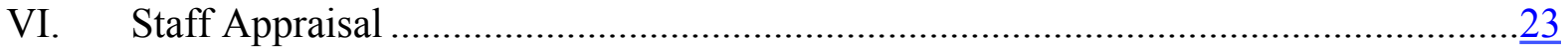

Tables

1. Mexico: Selected Economic, Financial, and Social Indicators, 2007-2011 ..............24

2. Mexico: Financial Operations of the Public Sector, 2007-2015 ...........................25

3. Mexico: Summary Balance of Payments, 2007-2015 ...........................................26

4. Mexico: External Financing Requirements and Sources, 2007-2012 _....................27

5. Mexico: External Debt Sustainability Framework, 2005-2015 ..............................28

6. Mexico: Gross Public Sector Debt Sustainability Framework, 2005-2015 ..............29

7. Mexico: Indicators of Fund Credit, 2010-2015 ................................................

8. Mexico: Financial Soundness Indicators ...........................................................

9. Comparison of Access in Fund Arrangements .....................................................32

10. FCL for Mexico-Impact on GRA Finances.....................................................

Figures

1. Mexico: Evolution of the Economy, 2004-2010 ............................................ $\underline{5}$

2. Mexico: Inflation and Monetary Policy ............................................................

3. Mexico: Financial Market Developments, 2008-2010 ..........................................

4. Mexico: Reserve Coverage in International Perspective .........................................12

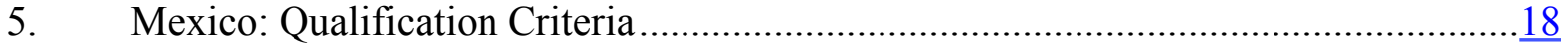

6. Mexico: External Debt Sustainability: Bound Tests............................................19

7. Mexico: Gross Public Debt Sustainability: Bound Tests.........................................20

Boxes

1. The 2011 Budget Proposal ............................................................................... 10

2. Illustrative Adverse Scenario ......................................................................... 14

Attachment

Letter from the Authorities Requesting Renewal of FCL 


\section{Context}

1. In the last decade and half before the global financial crisis, Mexico put in place very strong policy frameworks and substantially strengthened balance sheets. The inflation targeting regime has worked well, with inflation kept at low levels and expectations well anchored, with the flexible exchange rate working as a key shock absorber. Public debt levels were reduced, as fiscal policy has been guided by the balanced budget rule. Two major tax reforms in 2008 and 2010 demonstrate the authorities' commitment to bolster the structural fiscal position. Corporate sector balance sheets have been strengthened with low leverage and high profitability, while the banking system is well-capitalized and profitable.

\section{However, the Mexican economy was hit hard by the crisis reflecting especially its} close links to the U.S. The large shock to external demand and confidence resulted in an aggregate output decline of almost 9 percent between the fourth quarter of 2008 and the first quarter of 2009. Asset prices came under substantial pressure and confidence weakened sharply. From September 2008 through March 2009, the exchange rate depreciated by about 30 percent, external spreads rose by some $230 \mathrm{bp}$ for the sovereign and $800 \mathrm{bp}$ for corporates, and domestic government bond yields were also volatile with spikes of 200-300 bp at longer tenors. Corporates were essentially shut out from external financing during this period, reflecting difficulties experienced by some large Mexican multinationals, including from large foreign currency derivative related losses.

\section{The authorities mounted a comprehensive policy response to manage the crisis} related volatility. Investments in strengthening balance sheets and frameworks over the previous decade allowed implementation of a strong counter-cyclical macroeconomic policy response. Interest rates were cut by some 375 bps during the first half of 2009, and a fiscal stimulus of 3 percent of GDP was injected in 2009. Meanwhile, well-targeted interventions in financial and foreign exchange markets helped maintain orderly conditions, with careful use of rules based interventions and some lending and credit guarantees from public development banks in order to keep key market segments operating. Confidence was buttressed by contingent financing through a swap line from the U.S. Federal Reserve, the Flexible Credit Line arrangement from the Fund approved in April 2009, and additional external financing from multilateral lending agencies.

\section{Important actions have been taken on key medium term concerns related to} strengthening fiscal sustainability and boosting growth. The authorities followed the large stimulus in 2009 with the introduction of a front-loaded fiscal adjustment plan in 2010 to provide assurances on fiscal sustainability and involving the approval of structural tax measures worth some $1 \frac{1}{2}$ percent of GDP. On the structural side, the authorities have taken steps to improve the efficiency of the electricity sector, and have submitted to Congress reforms to strengthen competition and improve labor market flexibility. 


\section{EMERging From the Crisis}

5. The economy bottomed in mid-2009, but risks remained elevated (Figure 1). Growth resumed in the second half of 2009 on the back of strong exports to the U.S., Mexico's main trading partner and the economic normalization after the disruptions of the H1AN1 flu in April 2009 (Text Figure). However domestic demand remained mixed with some consumption recovery but investment still weak. Moreover, downside global risks remained a concern in a context of still elevated global risks and relatively low external buffers. As such, a new FCL arrangement was approved in March 2010 to

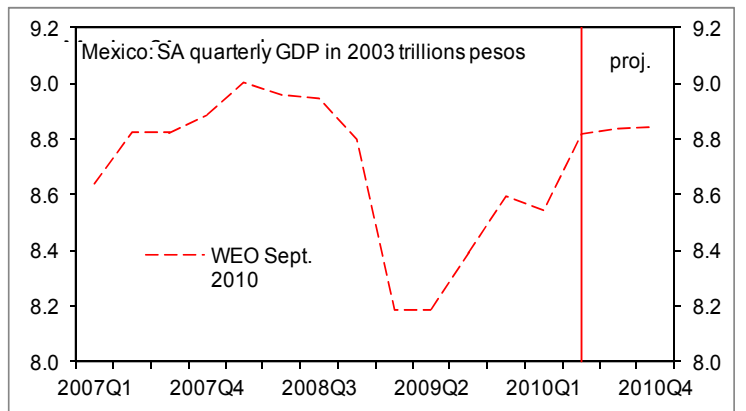
support the authorities' macroeconomic strategy.

6. Inflation has been falling in the context of a still important output gap (Figure 2). Core inflation has been on a declining trend following the one-off increase at the start of the year - related to the taxes approved in late 2009 and administered price increases - reaching 3.6 percent $y / y$ by end-November. Indeed, monthly core inflation has been rising by some 3 percent on an annualized basis during the last several months (the inflation target is 3 percent with a variability interval of $-/+1$ percent). Headline inflation has also been trending down this year, reflecting the favorable core inflation developments as also sharp drops in food prices. Nonetheless, recent hikes in electricity prices and unfavorable non-core food price developments have pushed up headline inflation to 4.3 percent in November.

\section{Financial market developments have been mixed this year-there are some early} signs of increased risk in recent weeks

(Figure 3). Asset prices and overall sentiment came under pressure in line with other emerging markets as fiscal concerns in peripheral European countries mounted over the summer.

Subsequently, the announcement that Mexico would be included in Citigroup's World Government Bond Index (WGBI) in October 2010 fueled large portfolio inflows and a sustained rally in the government bond market in the middle of the year. More recently, however, the local government yield curve has steepened, which could reflect increased investor caution (Text Figure). Moreover, an important component of recent capital flows likely also reflects more volatile short term carry trade flows. Exchange

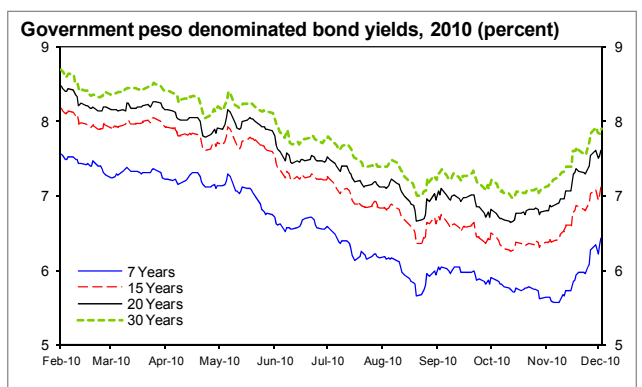
rate volatility has also picked up somewhat since April. 
Figure 1. Mexico: Evolution of the Economy, 2004-2010

The economy is in a cyclical recovery...

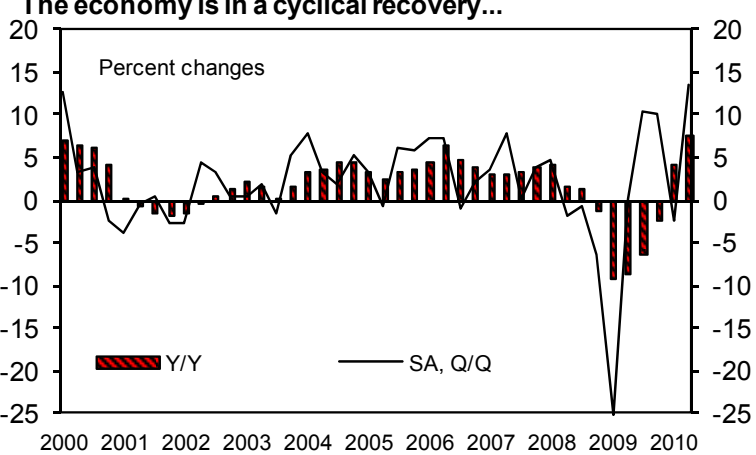

20002001200220032004200520062007200820092010

Production has moved in tandem with the US...

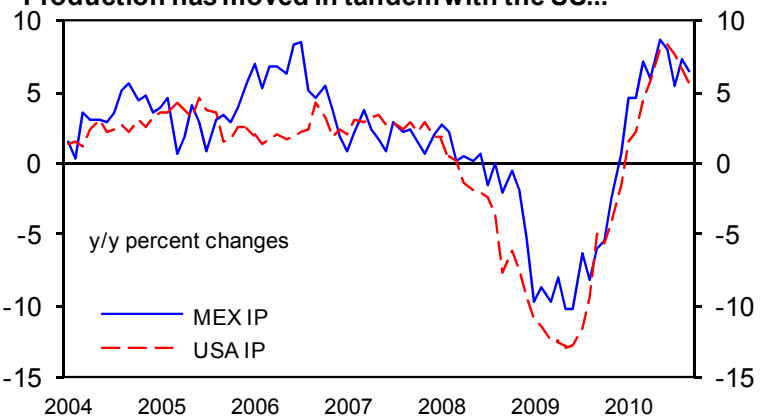

However, unemployment remains high.

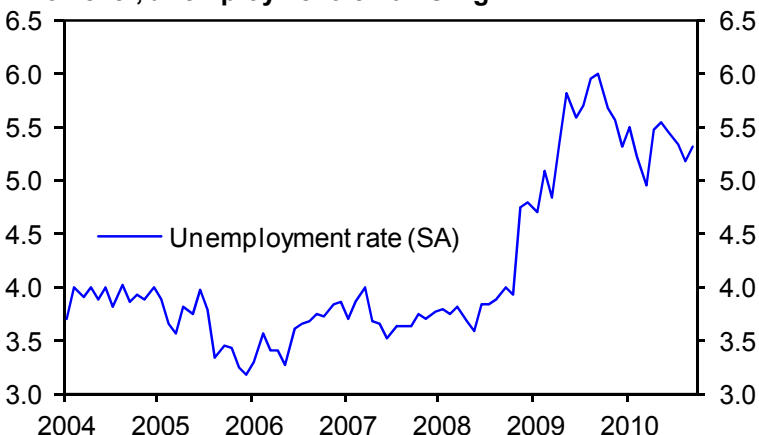

...with US industrial production expected to slow next year...

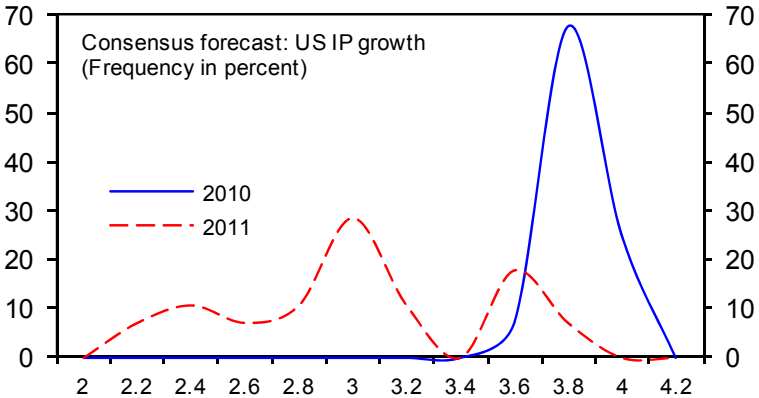

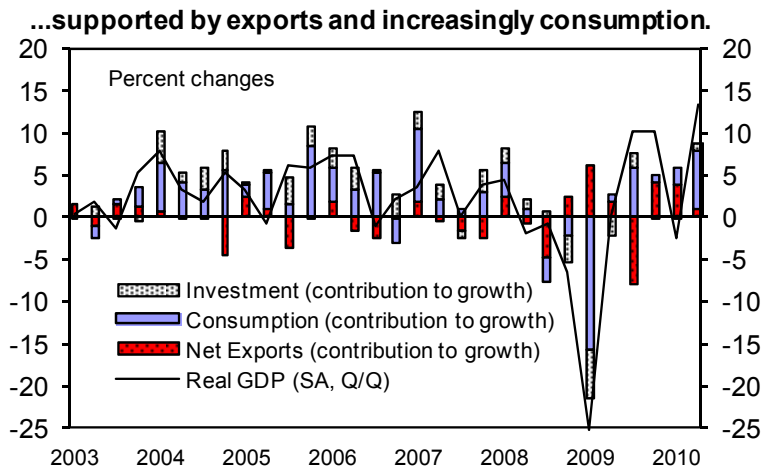
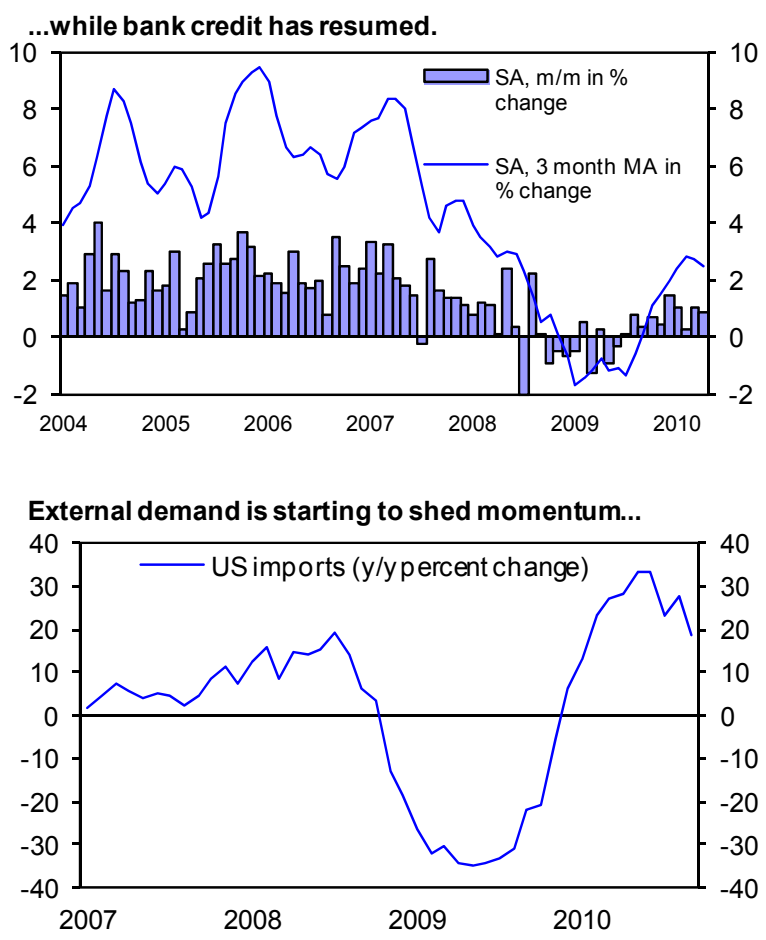

...while growth in Mexico too is expected to moderate in 2011.

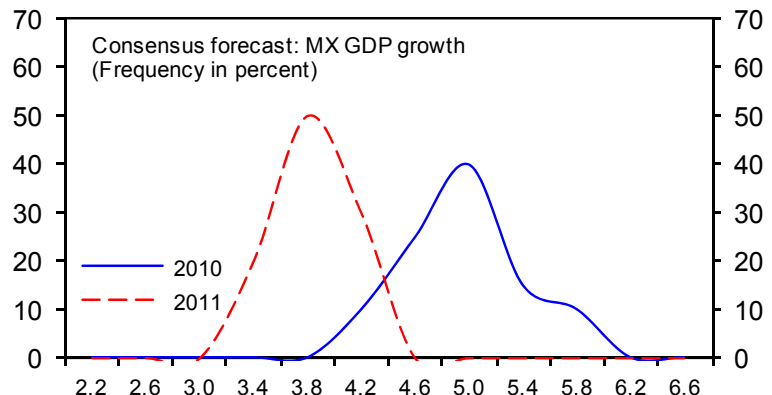

Sources: Consensus Forecasts; EMED; Haver Analytics; Banxico; and IMF staff calcualtions. 
Figure 2. Mexico: Inflation and Monetary Policy

With subdued demand, inflation has fallen faster than expected, with core inflation already below target...

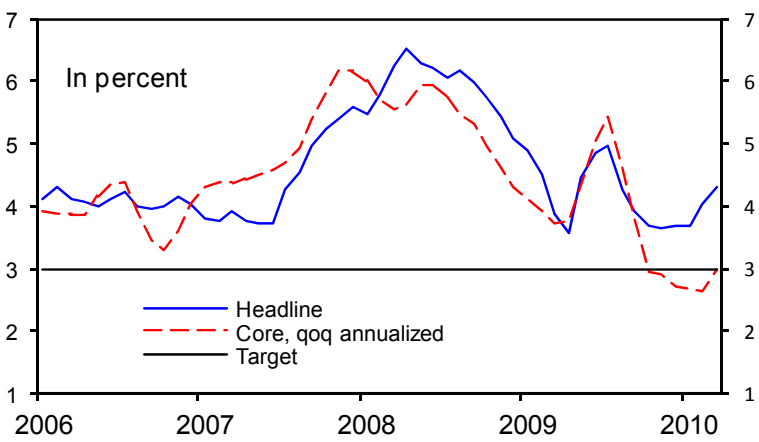

Inflation expectations remained contained...

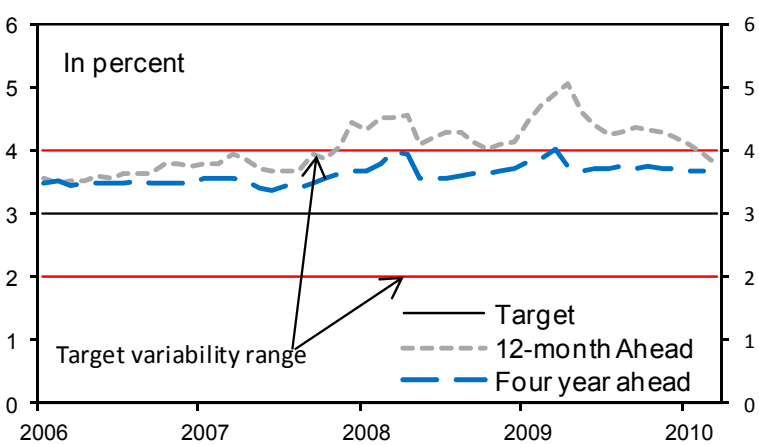

There remains important slack in the economy.....

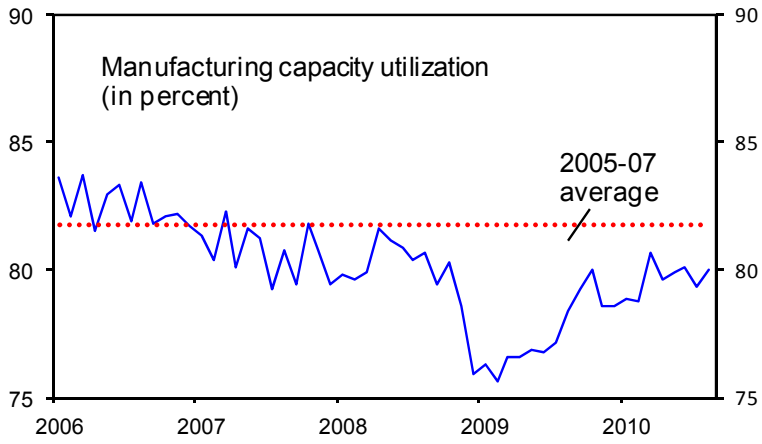

.... facilitating Banxico's supportive monetary stance...

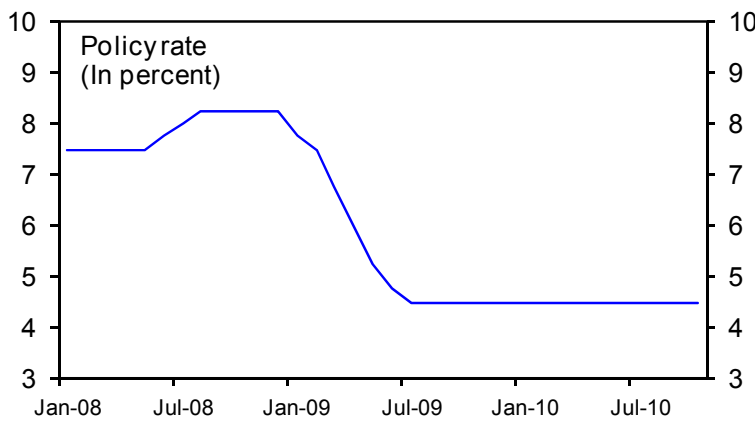

...and headline inflation pulled down by low food inflation.

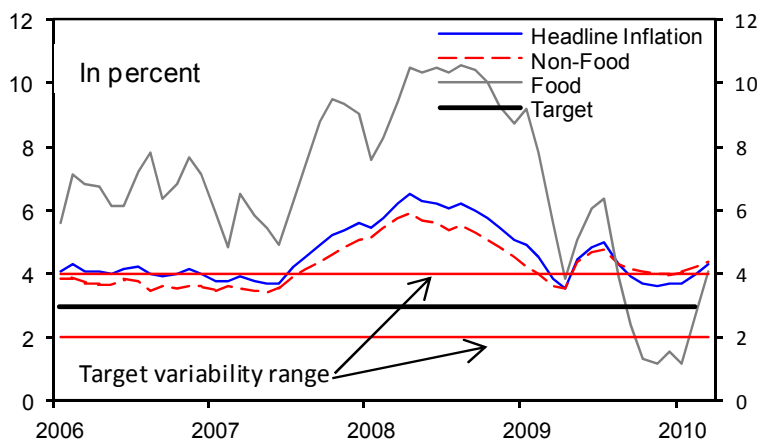

...as evidenced also in the bond market.

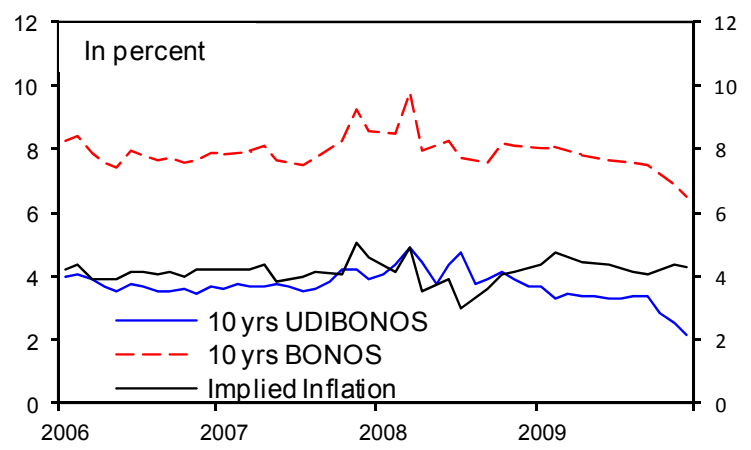

... while wage growth has been fairly stable...

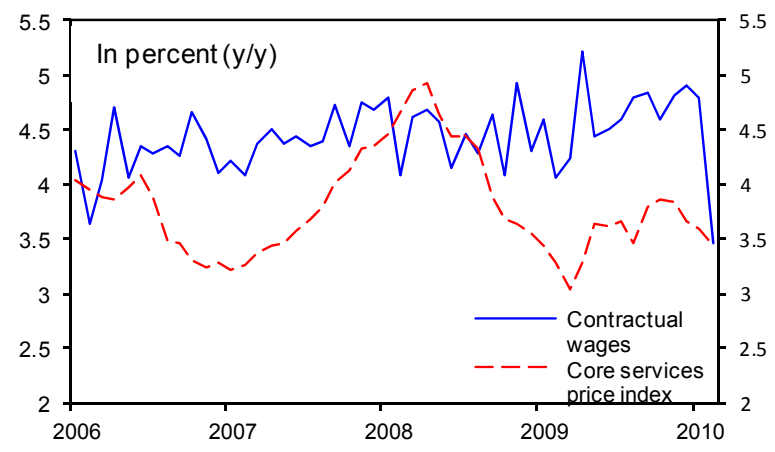

...so far broadly in line with others in the region.

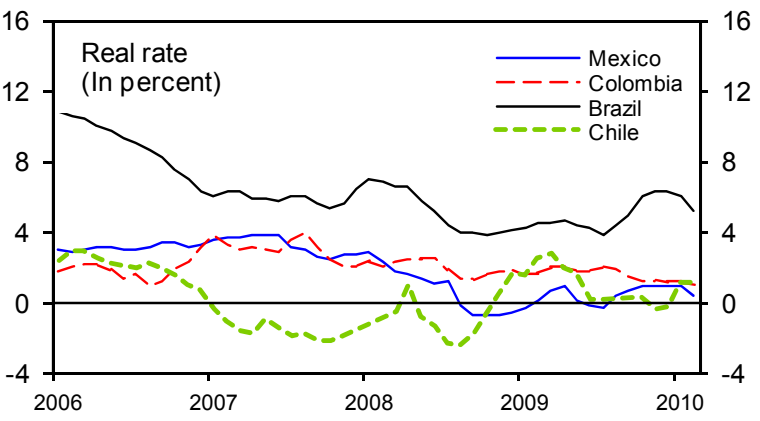

Sources: Bloomberg L.P.; Haver Analytics; INEGl; and IMF staff calculations. 
Figure 3. Mexico: Financial Market Developments, 2008-2010

Sovereign external risk spreads...

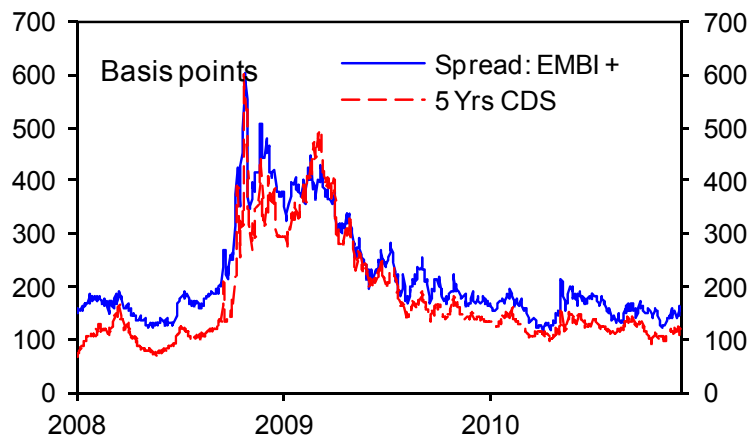

Corporate external spreads have also been contained...

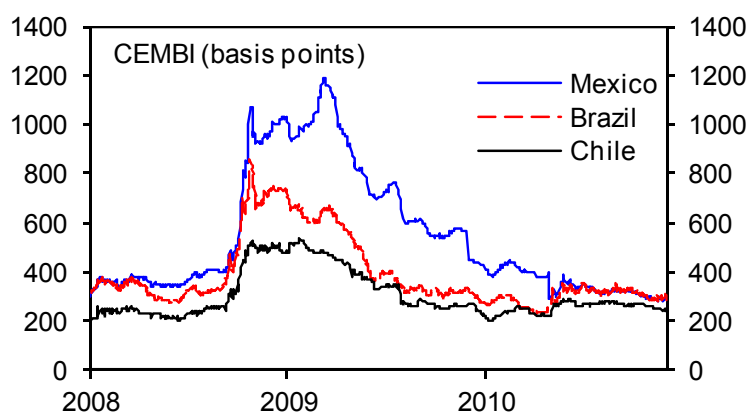

The rally in the local government bond market has stalled...

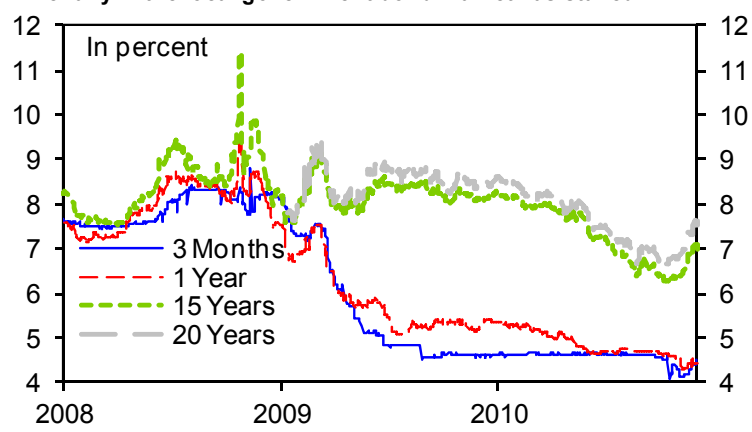

The swap curve has flattened as expectations of policy hikes have been postponed.

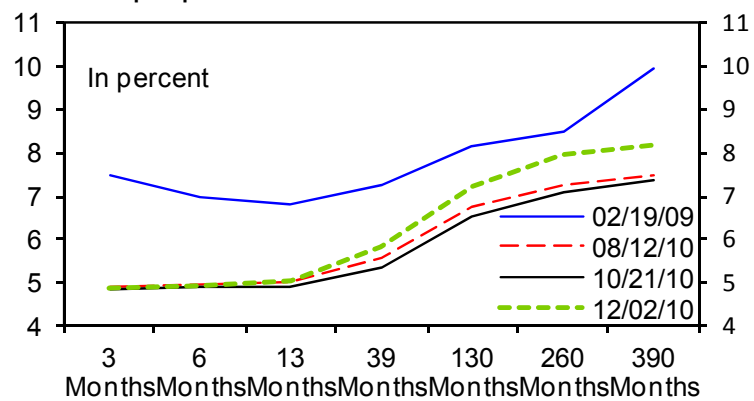

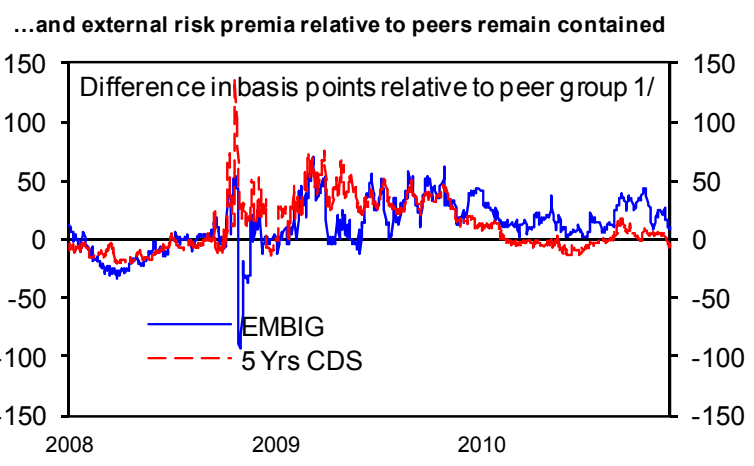

...while exchange rate based indicators of volatility have been subdued.

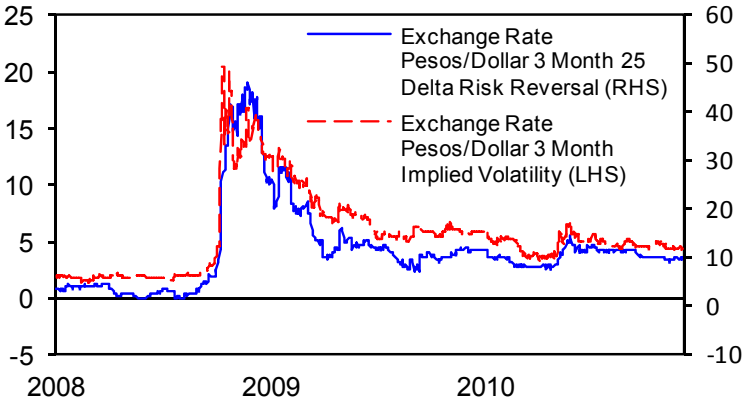

...after being driven partly by portfolio inflows

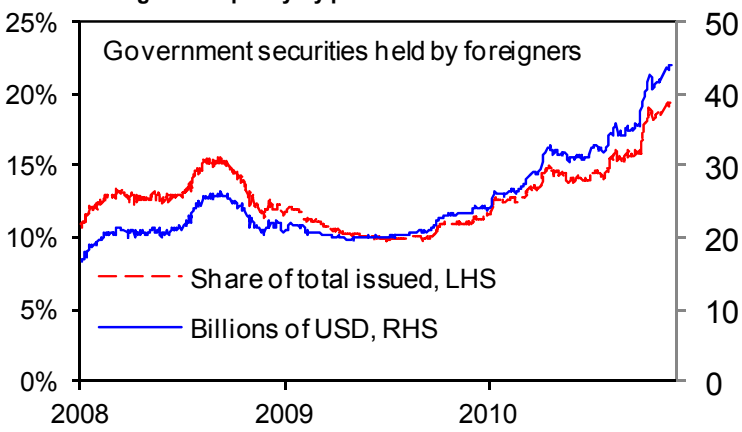

Meanwhile, the stock market has moved in line with the region.

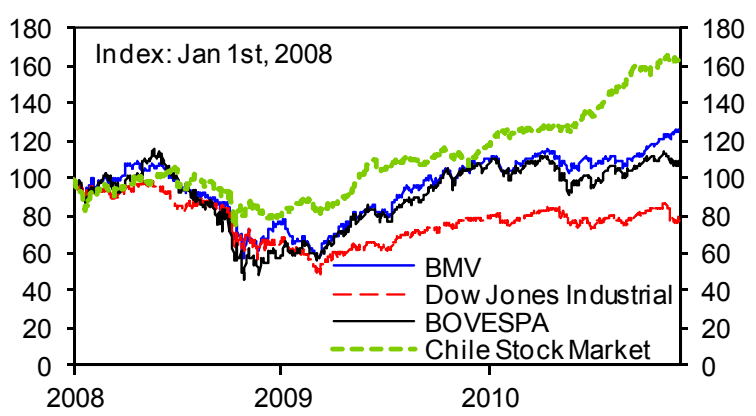

Sources: Bloomberg L.P.; Datastream; Haver Analytics; Mexican Authorities; IMF Information Notice System; and IMF staff calculations.

1/ Comparator group includes: Brazil, Chile, Colombia, Poland, and South Africa. 
8. The authorities have been able to meet their objectives on international reserves. In a context of higher portfolio debt flows noted in 97 , the exchange rate has strengthened, rising by about 5 percent against the dollar this year. Meanwhile, international reserves have risen by close to US $\$ 16$ billion during January-November However, capital inflows have been less than in other emerging market peers, in part reflecting Mexico's continued close links to U.S. and resulting uncertain longer-term growth prospects. Moreover, it is also important to note that the bulk of the US\$16 reserve increase this year reflects the effect Pemex oil sales (US\$9 billion) and public borrowing (US\$6 billion), with intervention contributing only about US\$4 billion.

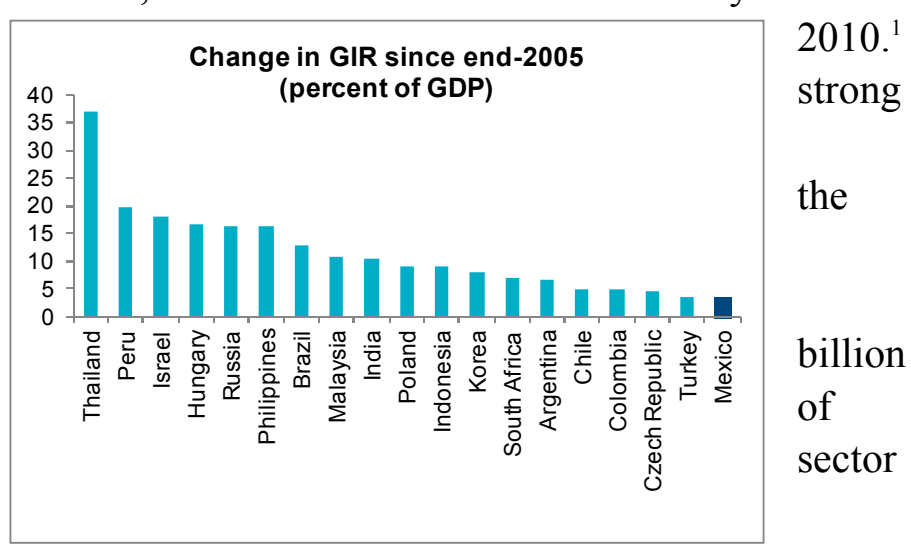
Indeed, reserve accumulation in Mexico has over the years been at the low end of the experience in emerging markets (Text Figure).

\section{The financial system remains resilient and there are signs that the credit cycle is beginning} to turn. After contracting for much of 2009, bank credit has started to grow in 2010, rising by 1.1 percent $y / y$ on average during the first three quarters, but rising to 5.9 percent $y / y$ by September. NPLs for the system have stabilized at low levels (about 2.7 percent of total loans) while banks remain liquid and well-capitalized. Local subsidiaries of global banks (which account for about 80 percent of the Mexican banking system) did not come under pressure in the most recent episode of global stress reflecting their intrinsic financial strength and reliance on retail funding in the Mexican market.

\section{OUTLOOK AND NeAR-TERM Policies}

10. Growth is expected to moderate next year. With prospects for a moderating U.S. recovery acting as a drag on external demand, growth in Mexico is projected to slow to 3.9 percent in 2011, broadly in line with the latest consensus. This outlook is predicated upon a further recovery in domestic demand as the key driver going forward, while the role of net exports diminishes. With the still wide - albeit gradually closing - output gap, inflation is projected to fall towards the 3 percent target (with a variability interval of $-/+1$ percent) by mid-2011. The external current account deficit is expected to settle at about $1 \frac{1}{2}$ percent of GDP during 2010-12, and the structure of external financing is expected to continue to shift away from the public to the private sector as firms continue to take advantage of easy external financing conditions.

\footnotetext{
${ }^{1}$ The 2010 Article IV staff report envisaged an increase of US\$15 billion in international reserves during the whole year 2010.
} 
11. Risks to the outlook have increased since earlier this year. Key downside risks facing Mexico center around the outlook for external demand and financing conditions. Risks around the baseline U.S. growth outlook are tilted to the downside, generating similar concerns for Mexico, which depends on the U.S. for 80 percent of its exports. Moreover, unease over the large global sovereign financing requirements, and ongoing fiscal concerns in Europe could yet generate another round of contagion, adversely affecting sentiment even for strong emerging markets such as Mexico. These risks are highlighted by the large balance sheet investments of North American and European investors in Mexico (Text Figure).

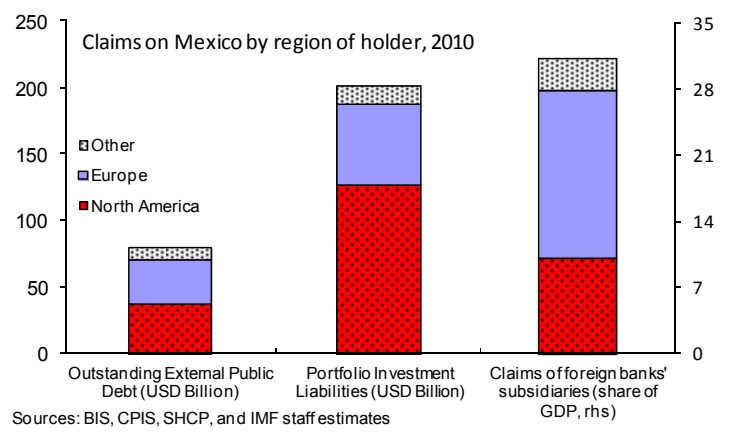
While easy global liquidity conditions have driven an international portfolio shift toward emerging market assets, materialization of such risks could spark a rapid unwinding of the recent inflows, exacerbating the resulting financial stress. Downsides arise also from tail risks for disorderly global currency adjustment pressures in the period ahead.

\section{The policy mix appropriately consists of a supportive monetary stance while fiscal policy is set on consolidation.}

- In a context of still elevated economic slack, fiscal withdrawal, and core inflation on a declining trend, an accommodative monetary stance is appropriate to support private consumption and investment. Survey-based expectations and the swap curve suggest that a tightening cycle is not likely before 2012. In the context of their inflation targeting regime, the authorities could also consider further easing if the recent appreciation pressures prove sustained and translate into lower inflation and inflation expectations.

- The authorities are implementing their fiscal consolidation strategy. The budget is on track to withdraw the equivalent of some 2 percent of GDP of stimulus during 2010, as envisaged in the Article IV consultation. Non-oil tax revenues are growing in line with the budget projections, which envisaged revenue gains on the order of 1 percent of GDP from the tax package approved in late 2009. The just approved 2011 budget includes additional spending measures that would help reduce the augmented fiscal deficit by about $1 / 4$ percent of GDP to $3 \frac{1}{2}$ percent of GDP in 2011. As discussed in Box 1, the budget remains broadly in-line with the fiscal strategy outlined in 2009 for returning to a zero deficit under the balanced budget rule target by 2012 . 


\section{Box 1. The 2011 Budget Proposal}

The 2011 budget proposal is broadly in line with the fiscal strategy spelled out in late 2009 in response to the global financial crisis. To smooth the effects of the crisis, the authorities invoked the exceptional circumstances clause under the balanced budget fiscal rule. As such, small fiscal deficits under the rule of 0.7 percent of GDP and 0.3 percent of GDP were envisaged in 2010-11 to account for the cyclical deterioration in the fiscal position and offset the shortfall in domestic demand. A return to a balanced budget under the rule was envisaged for 2012. At the same time, a fiscal consolidation package was introduced in 2010 to offset the deterioration in the structural fiscal position arising from the decline in oil production experienced through 2009.

The budget is in line with a deficit under the rule of 0.5 percent of GDP (excluding investment by PEMEX). Oil production is projected to reach 2,550 million barrels per day (same level as in 2010) and oil prices are projected conservatively under the rules-based formula at U\$S65.4/bbl. Most importantly, the ceilings for saving oil revenue windfalls remain suspended as they were in 2010 . As such, there is scope for fiscal savings to be higher than planned. While real fiscal revenues are expected to grow 2.5 percent in 2010 , real primary spending is projected to fall 1.2 percent. All told, fiscal policy is currently projected to withdraw close to 0.8 percent of GDP of stimulus during 2011. With the primary position still in deficit, gross public debt is estimated to increase from 45.1 percent of GDP in 2010 to peak at 45.9 percent of GDP in 2011, gradually falling over the Mexico. 2011 Budget Proposal 1/

\begin{tabular}{lcc}
\hline & 2010 & 2011 \\
\cline { 2 - 3 } & Proj & Budget \\
\hline Revenue & 22.5 & 22.3 \\
Oil & 7.3 & 7.3 \\
Tax & 10.5 & 10.6 \\
Other & 4.7 & 4.2 \\
Expenditure & 25.3 & 24.9
\end{tabular}

Traditional balance $\quad-2.7 \quad-2.6$ without PEMEX investment $\quad-0.7 \quad-0.5$

Adjustments $\quad 0.8 \quad 0.9$

Augmented balance $\quad-3.6 \quad-3.5$

Memo:

Cyclically adjusted balance 2/ $\quad-5.0 \quad-4.3$

1/ Preliminary estimates (in percent of GDP).

2/ Domestic resource balance. medium term.

In contrast to the 2010 budget, the 2011 budget does not envisage significant fiscal measures. An increase of excise taxes for tobacco products and some beverages, projected to yield 0.1 percent of GDP, will be complemented by continuing efforts to strengthen tax compliance via a streamlining of the procedures followed by tax payers to pay their tax obligations and by revamping tax audits. The fiscal regime of Pemex is expected to be modified to improve incentives to increase production in marginal fields (i.e., fields with high costs of production that are non-viable under the current regime). 


\section{Role OF THE FLeXIBLe Credit Line}

\section{Continued global uncertainties and attendant external risks remain key concerns}

facing Mexico. As discussed in the October 2010

GFSR, progress towards improving overall

financial stability suffered a set-back over the summer (Text Figure), reflecting increased macroeconomic risks. The external environment since then has continued to be highly volatile, with key concerns including the mix of fiscal pressures in peripheral European advanced economies, longer term fiscal concerns in other countries, and the more recent currency and capital flow volatility related to persisting global imbalances.

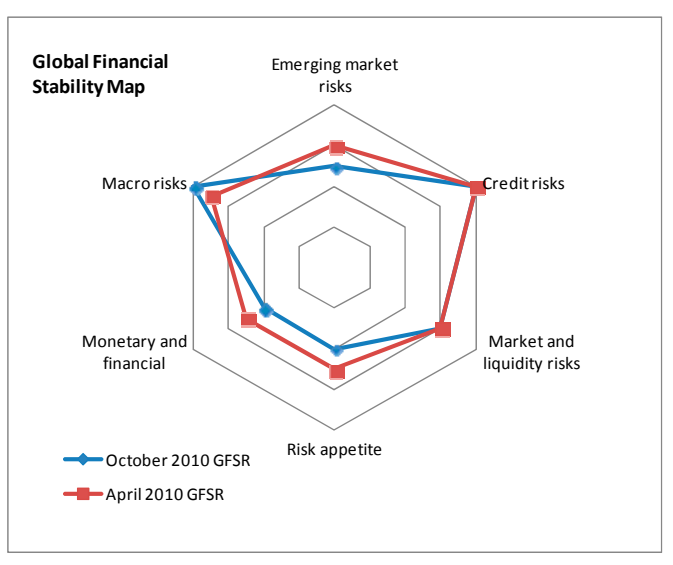

14. In the face of this situation, the authorities continue to seek additional insurance against external risks, including through a successor FCL arrangement. Mexico's international reserves are low relative to key balance sheet exposures that could reverse in periods of severe stress (Figure 4). This concern weighed on investor sentiment during the crisis, and was a key factor behind the authorities' strategy to request additional insurance from the Fund in 2009-10, while also seeking to increase somewhat their international reserve position. With global risks having increased since the approval of the current FCL, a reduced room for policy maneuver amongst major economies (given especially shrinking fiscal space) were additional unanticipated shocks to arise, and the expiration of the Fed swap, the authorities would like to request the Fund to approve a successor FCL arrangement.

15. Indeed, the authorities believe that Mexico needs to grasp the opportunity afforded by the recent Fund facilities reform to expand insurance against external risks and thus are requesting a new 2-year precautionary $F C L$ arrangement for 1,500 percent of quota (about US $\$ 73$ billion). ${ }^{2}$ The enhanced FCL provides more flexibility in terms of access and length. The authorities would like to take advantage of these features - which they would have done in previous arrangements had this been possible at the time - and which they see as better suited to insuring against the risks Mexico is facing. Indeed, another higher access, longer-tenor FCL arrangement would provide necessary insurance against tail risks that have persisted for longer than anticipated at the time of approval of past FCL arrangements, allowing more time for shocks to dissipate and increasing policy flexibility. While they continue to take advantage of currently favorable market conditions to increase somewhat their own reserve cushion, they view the reformed FCL as an increasingly close substitute for reserves, one that will support their commitment to the fully flexible exchange regime and desire to avoid non-price mechansims to manage capital flows.

\footnotetext{
${ }^{2}$ Access at 1,500 percent of quota would carry an annual commitment fee of 38 bps (179.7 million SDR) per annum.
} 
Figure 4. Mexico: Reserve Coverage in International Perspective 1/
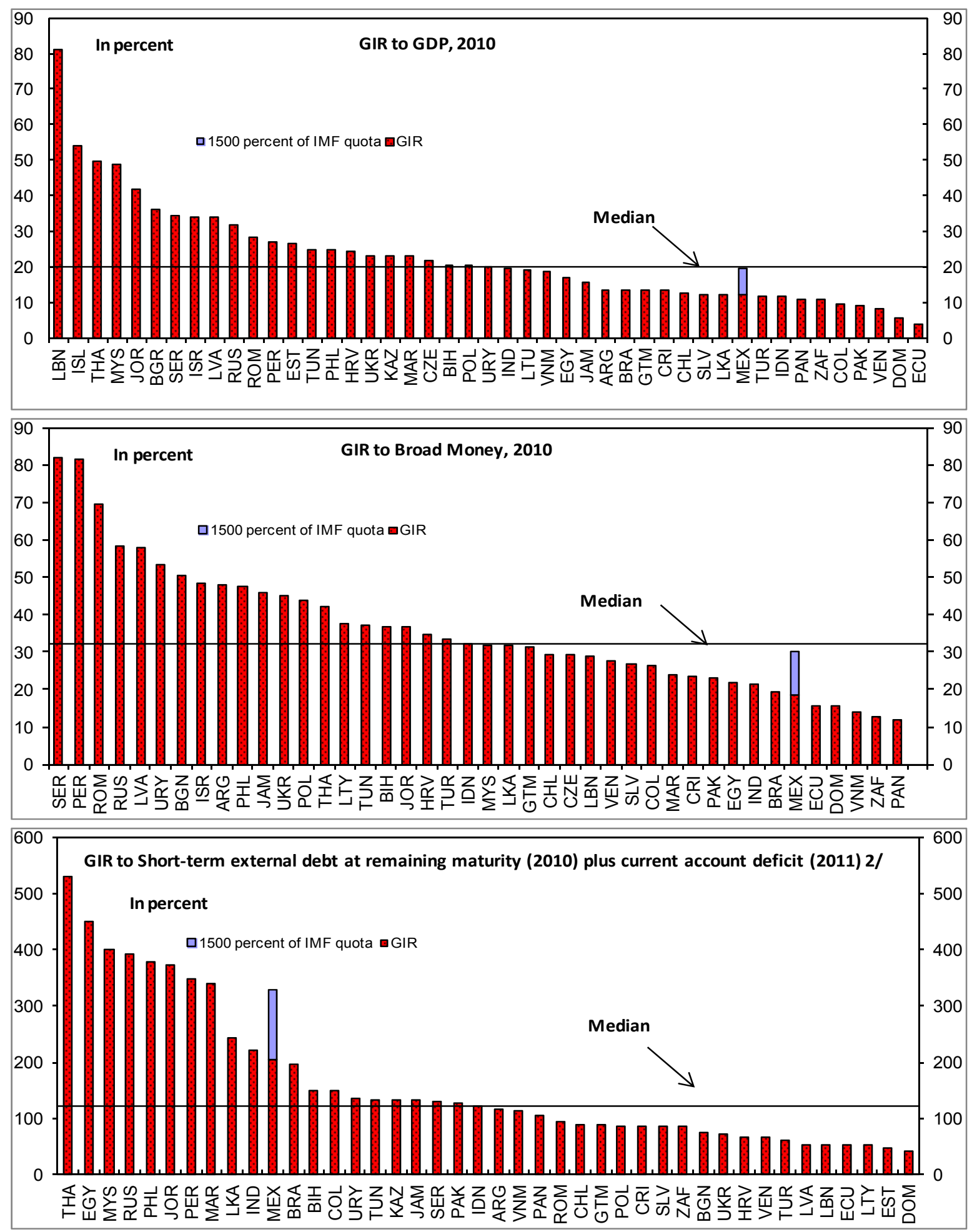

Sources: World Economic Outlook and IMF staff estimates.

1/ Estimates for 2010.

2/ GIR at the end of 2010 in percent of ST debt at remaining maturity and current

account deficit in 2010. The current account is set to zero if it is in surplus. 


\section{Access Considerations}

\section{The access case rests on the interplay of drains under a plausible downside scenario, combined with other tail risks and Mexico's need to boost external insurance.}

- Downside risks. With the global financial crisis far from over, Mexico remains exposed to important downside risks. Indeed, as noted in $\$ 13$, global risks have increased since the approval of the previous FCL in March 2010. As such, high access is needed to provide credible assurances of sufficient liquidity under a stress scenario. A reasonable - albeit not extreme-scenario is presented in some detail in Box 2. The

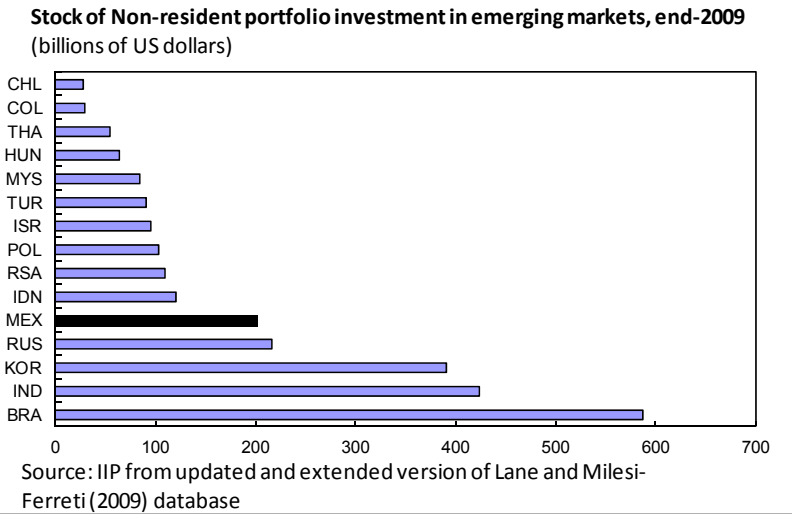
rtfolio investment in emerging markets, end-2009 shocks used in the scenario are broadly in line with those used in adverse scenarios developed for other FCL cases. Meanwhile, assumed rollover rates are better than assumed in the scenario for the 2009 Mexico FCL, but worse than those assumed in the 2010 FCL. Altogether this scenario could yield a reserve drain of up to about US\$45 billion. ${ }^{3}$

- $\quad$ Non-resident exposures. While the stress scenario above considers some portfolio outflows, these are hard to predict, and it is not an extreme scenario. Mexico continues to have very large non-resident investments in portfolio equity and domestic debt instruments. This generates additional tail risks, particularly in the face of a global systemic shock.

- $\quad$ Greater uncertainty from longer duration. Uncertainty around a baseline is naturally larger for a longer horizon, which in the current case would also straddle the 2012 Presidential elections. ${ }^{4}$

\footnotetext{
${ }^{3}$ The scenario considers independent one-year shocks in 2011 and separately in 2012 such that the individual year gaps are not being added together. In a scenario where shocks were to persist for more than one year, the impact on the external gross financing requirement gap could be higher.

${ }^{4}$ Nonetheless, the incremental impact of increasing uncertainty in 2012 considered in the adverse scenario here is small (less than US\$5 billion of the US\$45 billion dollar gap in 2012 reflects this factor).
} 


\section{Box 2. Illustrative Adverse Scenario}

An illustrative adverse scenario developed by staff suggests a possible annual financing shortfall on the order of US\$35-45 billion for 2011-12. As highlighted in the

EWE/WEO/GFSR, risks to world growth in 2011 have shifted from balanced in April to the downside, including through concerns of a more marked slowdown in the U.S. and continued sovereign pressures in Europe. The following scenario illustrates the potential impact of these downside risks on Mexico, assuming a combination of slower global growth and elevated global risk aversion. It should be noted that the scenario applies independent shocks in 2011 and in 2012 to generate a risk envelope. It also allows for uncertainty to increase with time. ${ }^{1}$

\begin{tabular}{|c|c|c|c|c|c|c|c|c|c|}
\hline & \multicolumn{7}{|c|}{$\begin{array}{l}\text { Mexico. Calculations of financing shortfalls over 2011-12 } \\
\text { (In billions of U.S. dollars) }\end{array}$} & & \\
\hline & \multicolumn{5}{|c|}{ Baseline } & \multicolumn{2}{|c|}{ Adverse scenario } & \multicolumn{2}{|c|}{ Fin Shortfalls } \\
\hline & 2008 & 2009 & 2010 & 2011 & 2012 & 2011 & 2012 & 2011 & 2012 \\
\hline Current account & -16.2 & -5.7 & -11.6 & -14.6 & -16.3 & -21.0 & -23.5 & -6.5 & -7.2 \\
\hline Net oil exports & 15.0 & 10.4 & 5.7 & -0.3 & -6.4 & -0.2 & -5.5 & 0.0 & 1.0 \\
\hline Net services exports (incl. tourism) & -7.1 & -8.0 & -9.0 & -9.6 & -10.3 & -10.3 & -11.2 & -0.7 & -0.9 \\
\hline Net transfers (incl. remittances) & 25.5 & 21.5 & 22.1 & 25.7 & 28.4 & 19.9 & 21.2 & -5.8 & -7.2 \\
\hline FDI net & 22.5 & 6.4 & 8.4 & 18.0 & 19.5 & 11.5 & 11.3 & -6.5 & -8.2 \\
\hline Public sector, gross MLT flows & 24.9 & 19.1 & 16.9 & 13.4 & 12.7 & 13.4 & 12.7 & 0.0 & 0.0 \\
\hline Private sector, gross MLT flows & 13.4 & 18.7 & 22.4 & 17.5 & 25.4 & 10.9 & 15.5 & -6.6 & -9.9 \\
\hline Short-term financing gross & 25.2 & 24.5 & 20.0 & 23.2 & 27.1 & 16.4 & 18.9 & -6.8 & -8.2 \\
\hline Peso-denominated portfolio debt net & 6.0 & 3.5 & 17.0 & 8.8 & 6.0 & 4.3 & 0.5 & -4.5 & -5.6 \\
\hline Assets: debt and other investment gross & -7.9 & -11.0 & -9.0 & -10.5 & -11.3 & -15.0 & -16.9 & -4.5 & -5.7 \\
\hline Total identified shortfall & & & & & & & & -35.3 & -44.6 \\
\hline
\end{tabular}

- The current account deteriorates by US\$6-7 billion. Weaker external demand is assumed in the scenario to have only a limited effect on non-oil net exports given their high import content. Meanwhile, with Mexico becoming a net oil importer in 2011-12, lower oil prices would shrink the gap. However, a shock to tourism just below US\$1 billion (bringing it back to 2009 levels) is assumed, reflecting weaker external demand. Also, were growth in the U.S. to falter, including in the housing sector - in which Hispanic employment is concentrated - remittances could fall substantially. With already high long-term unemployment amongst Hispanics, another shock is assumed to drive a drop in transfers in the range of US\$ 6-7 billion (about 13/4-21/4 standard deviations).

- FDI falls by US\$6 $1 / 2-8$ billion reflecting weaker global economic prospects and tighter financial conditions. This is a far smaller shock than was actually observed in 2009, when there were also sizable FDI outflows.

- Public external financing is unaffected, reflecting the authorities' prudent debt management and their strong track record of securing external access. As such, the scenario assumes that the authorities can carry out their financing strategy as planned in the baseline.

Amidst a flight to safety, greater pressures are considered on private sector financing, non-resident portfolio flows, and resident outflows. 
- Private sector medium and long term flows fall by US\$7-10 billion. This reflects a drop in rollover rates assumed from 1.3 to 0.8 , albeit still significantly higher than those seen in typical capital account crisis cases.

- Short-term financing falls by US\$7-8 billion, assuming about 80 percent of short-term financing is rolled over versus 120 percent in the baseline - broadly in line with the minimum levels observed in recent years before the crisis.

- Portfolio debt inflows fall by US\$4 $\$ 1 / 2-51 / 2$ billion reflecting a partial reversal of the large inflows seen in 2010, as foreign investors retrench. Moreover, during the crisis period of 2008Q4-2009Q1, net portfolio debt flows fell to US\$ -5 billion, a larger drain than in the current adverse scenario.

- Resident outflows abroad rise by US\$ $\$ \frac{1 / 2-51 / 2}{2}$ billion. These flows are highly volatile and a $2-2 \frac{1}{2}$ standard deviation shock is considered here. Moreover, the computation of the shock excludes the large outflow in 2007 which likely biases down the impact.

${ }^{1}$ As noted, the exercise assumes independent shocks in 2011 and 2012; were the shocks to last more than one year, the financing gap could be larger. Also, shocks as appropriate in 2012 are assumed to be 30 percent larger than in 2011, consistent with the April 2010 WEO, which envisaged a downside risk band about 1.3 times as wide for 2011 as that for 2010. It should be noted though that the standard deviations are computed over 200408 during which Mexico maintained very strong policy frameworks and also straddling a period of relative global tranquility. Computing the variance over longer periods would generate larger shocks than those considered here.

- $\quad$ Reserve coverage. Reserves have increased this year, broadly in line with the authorities program as described in the 2010 Article IV consultation, although coverage ratios have not increased much (or even fallen), given the growth in the denominators used to compute these ratios. ${ }^{5}$ Meanwhile, other buffers have fallen with the expiration of the US $\$ 30$ billion Fed swap in January. While rules of thumb are met for some standard metrics, reserve Mexico: Comparis ons under various reserve adequacy metrics at end-2010

\begin{tabular}{|c|c|c|c|c|}
\hline & Mexico & $\begin{array}{l}\text { Lat Am EM } \\
\text { Median 1/ }\end{array}$ & $\begin{array}{l}\text { Mexico at } \\
\text { Median 2/ }\end{array}$ & Difference 3/ \\
\hline & \multicolumn{4}{|c|}{ (In percent, unless otherwise indicated) } \\
\hline Reserves to imports 4/ & 4.4 & 8.1 & 226 & 103 \\
\hline Reserves to Broad Money & 17.6 & 28.6 & 198 & 76 \\
\hline Reserves to GDP & 12.2 & 13.1 & 132 & 9 \\
\hline Reserves to portfolio investment $5 /$ & 60.9 & 98.2 & 198 & 75 \\
\hline \multicolumn{5}{|c|}{ Source: WEO and Lane and Milessi-Ferreti. } \\
\hline \multirow{2}{*}{\multicolumn{5}{|c|}{$\begin{array}{l}\text { 1/ Latin America emerging market countries are Argentina, Brazil, Chile, Colombia, Mexico, } \\
\text { Peru, Uruguay and Venezuela. }\end{array}$}} \\
\hline & & & & \\
\hline \multicolumn{5}{|c|}{$\begin{array}{l}\text { 2/ Reserves in Mexico (in USD billions) consistent with the Latin American Emerging } \\
\text { market median. }\end{array}$} \\
\hline \multirow{2}{*}{\multicolumn{5}{|c|}{$\begin{array}{l}\text { 3/ Difference in US millions between column } 3 \text { and the } 2010 \text { level of reserves in Mexico. } \\
\text { 4/ In months of imports. }\end{array}$}} \\
\hline & & & & \\
\hline 5/ Evaluated us ing end-2009 portfol & investment. & & & \\
\hline
\end{tabular}
coverage remains relatively low against balance sheet indicators (such as investment positions of non-residents and financial depth). Moreover, the relatively low reserve

\footnotetext{
${ }^{5}$ The increase in reserves during 2009-10 is envisaged to improve somewhat coverage in terms of GDP (from 11.4 to 11.9 percent) during this period; however, it implies a slight decline in terms of broad money (from 17.8 to 17.6 percent) as well as relative to imports (from 4.6 to 4.4 months).
} 
cover compared to other emerging markets peers has been a key factor of concern for markets, including in 2009, and the buffer implicit in the requested access would provide reassurance and lessen incentives to self-insure.

\section{Putting these elements together, the staff supports the authorities' request. The} proposed access equivalent to some US\$73 billion would cover the potential drains discussed in the adverse scenario (US\$45 billion) while allowing a sufficiently large cushion for additional tail risks also considered (of the order of US\$25-30 billion, similar to Mexico's previous FCL arrangements). Such an access level would also bring Mexico's reserves to broad money ratio - a key balance sheet metric - to the median of the sample of emerging market countries considered here (Figure 4$)^{6}{ }^{6}$

\section{Review of Qualification}

\section{The staff believes that Mexico fully meets the qualification criteria for an} arrangement under the FCL (Figure 5). The authorities continue to have in place very strong policy frameworks. These include monetary policy guided by the inflation targeting framework in the context of the flexible exchange regime, and fiscal policy anchored by the balanced budget rule. The authorities have demonstrated on numerous occasions their resolve to continue maintaining such policies going forward, including with the passage of major fiscal reforms in the 2010 budget. Indeed, the Executive Board commended Mexico's very strong policy track record and frameworks at the conclusion of the 2010 Article IV consultation in March.

- $\quad$ Sustainable external position. The updated external debt sustainability analysis (Table 5 and Figure 6) continues to show that Mexico's external debt remains moderate (below 25 percent of GDP) and is expected to fall over the medium term even if shocks materialize.

- Capital account position dominated by private flows. The bulk of Mexico's external debt is still owed to private creditors, and private non-debt creating flows continue to be large relative to overall balance of payments flows.

- Track record of steady sovereign access to international capital markets at favorable terms. Mexico is among the highest rated emerging markets and its sovereign spreads remain low. As in other emerging markets, Mexico's spreads increased with the heightened stress of debt markets in Europe, but have since fallen

\footnotetext{
${ }^{6}$ This is an indicator of coverage against the risk of capital flight which has particular salience for emerging markets considering insurance against tail risk events as discussed in Maurice Obstfeld, Jay C. Shambaugh, and Alan M. Taylor, 2010. "Financial Stability, the Trilemma, and International Reserves," American Economic Journal: Macroeconomics, American Economic Association, vol. 2(2), pages 57-94, April.
} 
back. Since March 2010, the government has successfully placed about US\$5 billion in sovereign bonds in international markets. ${ }^{7}$

- Relatively comfortable reserve position. Mexico's reserves were viewed as comfortable for normal times before the crisis. They have been rebuilt to about US $\$ 114$ billion after having declined to US\$75 billion during the crisis. This is consistent with the government's objective of increasing its level of external insurance (as described in www.imf.org), reflecting its lower coverage on balance sheet exposures relative to peers that was a concern for investors in the context of the crisis. Moreover, developments since the fall CGER assessment indicates that the real exchange rate continues to be broadly in line with fundamentals at the current juncture, and the authorities remain committed to the flexible exchange regime, in the context of rule-based mechanisms to increase somewhat their reserves.

- $\quad$ Sustainable public debt position and sound public finances. Fiscal policy remains underpinned by the balanced budget rule, and the authorities' commitment to keep the augmented public sector deficit at a level that stabilizes total public debt. The updated debt sustainability analysis continues to show a gradual decline in the public debt to GDP ratio and to suggest that the debt trajectory is broadly robust to most standard shocks (Figure 7 and Table 6). Nonetheless, the fiscal outlook is sensitive to growth dynamics and the evolution of oil prices, including regulated domestic prices for petroleum products. Shocks here would require offsetting adjustment measures under the fiscal rule, which provides assurances on fiscal sustainability. Fiscal outturns in 2010 are broadly in line with the budget, and fuel prices have been raised as envisaged at the time of the March 2010 Article IV consultation. Moreover, the authorities' solid track record is a testament to their strong commitment to prudent fiscal policies and their ability to respond to unanticipated shocks.

- Low and stable inflation. After rising early in the year (partly owing to the fiscal measures adopted), headline and core inflation have been falling somewhat faster than envisaged (see 96 ), and headline inflation is on track to converge to the 3 percent target (with a variability interval of $-/+1$ percent) by mid-2011. Inflation expectations remain well-anchored.

\footnotetext{
${ }^{7}$ In April, the authorities placed US $\$ 1$ billion of 30-year bonds at a premium of 137.5 basis points over comparable US Treasuries, 7-year bonds for $€ 850$ million at a yield of 4.29 percent in July, 100-year bonds for US\$ 1 billion at a yield of 6.1 percent in early October, and a Samurai-bond for $¥ 150$ billion in mid-October.
} 
Figure 5. Mexico: Qualification Criteria

Sustainable external position

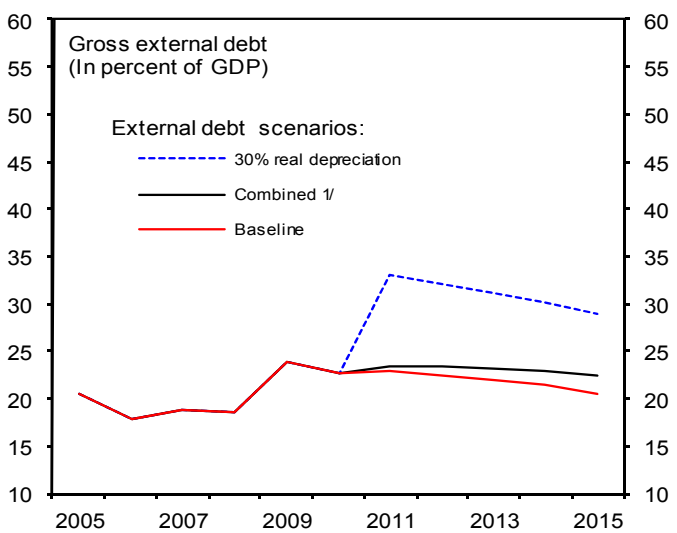

Steady sovereign capital markets access

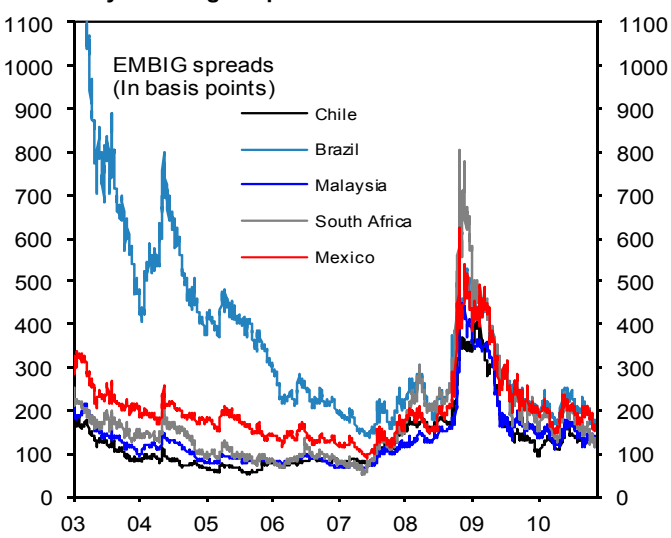

Sustainable public debt position

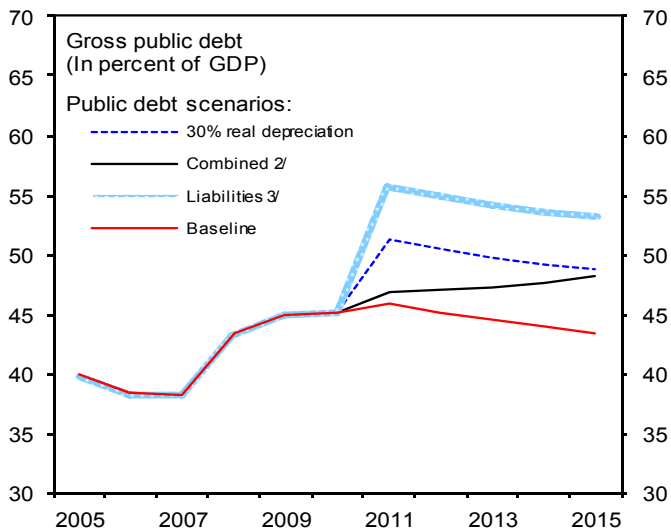

Almost all external debt to private creditors

Holders of gross external debt

(In percent of total external aPublic: $12 \%$

debt)

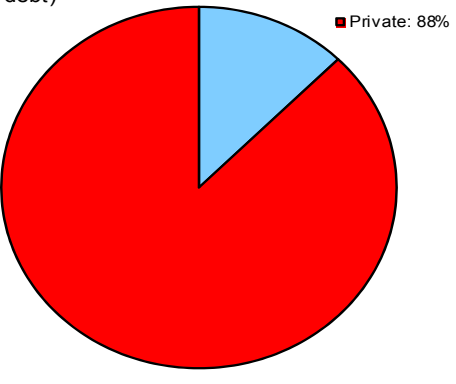

Comfortable reserve coverage

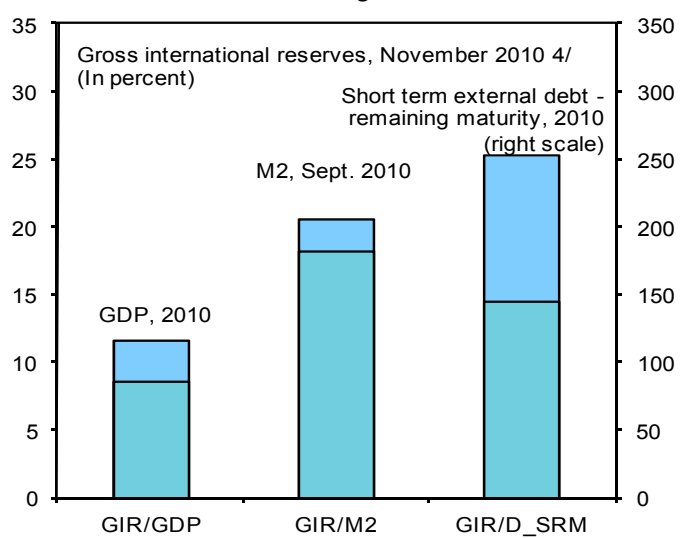

Low and stable inflation

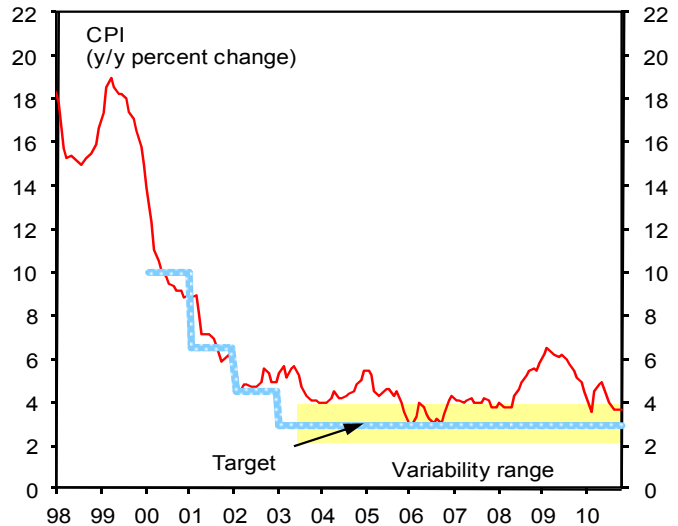

Sources: Bloomberg L.P.; Datastream; EMED; Haver Analytics; and IMF staff calculations.

$1 /$ Combined permanent $1 / 4$ stan dard deviation shocks applied to interest rate, growth, and primary current account balance.

$2 /$ Combined permanent $1 / 4$ standard deviation shocks applied to real interest rate, growth rate, and primary balance.

3/ One-time 10 percent of GDP increase in debt-creating flows.

4/ Lower bar shows the ratio as in SM/10/81. 
Figure 6. Mexico: External Debt Sustainability: Bound Tests 1/ (External debt in percent of GDP)
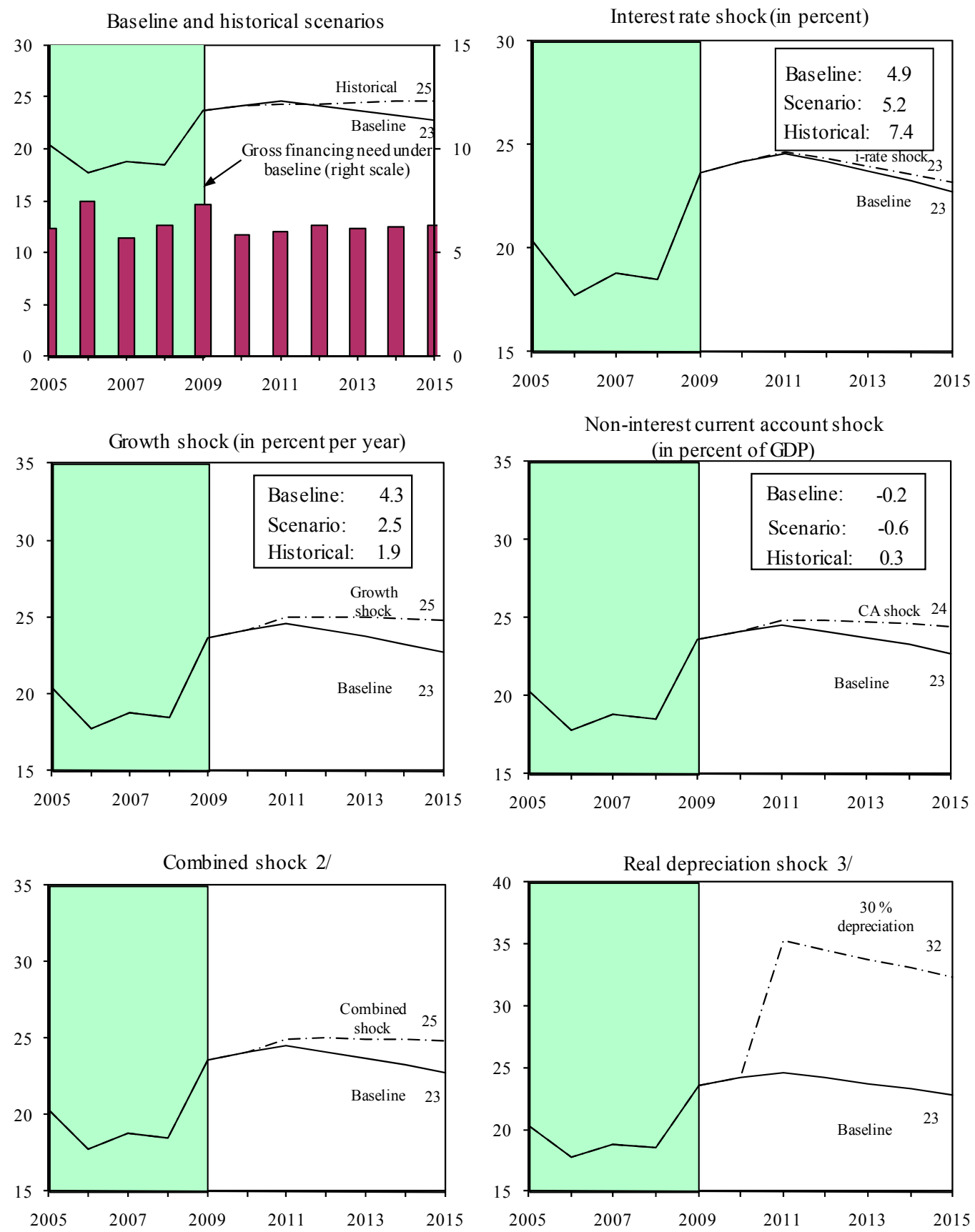

Sources: International Monetary Fund, Country desk data, and staff estimates.

1/ Shaded areas represent actual data. Individual shocks are permanent one-half standard deviation shocks. Figures in the boxes represent average projections for the respective variables in the baseline and scenario being presented. Ten-year historical average for the variable is also shown.

2/ Permanent 1/4 standard deviation shocks applied to real interest rate, growth rate, and current account balance.

3/ One-time real depreciation of 30 percent occurs in 2010. 
Figure 7. Mexico: Gross Public Debt Sustainability: Bound Tests 1/ (Gross public debt in percent of GDP)
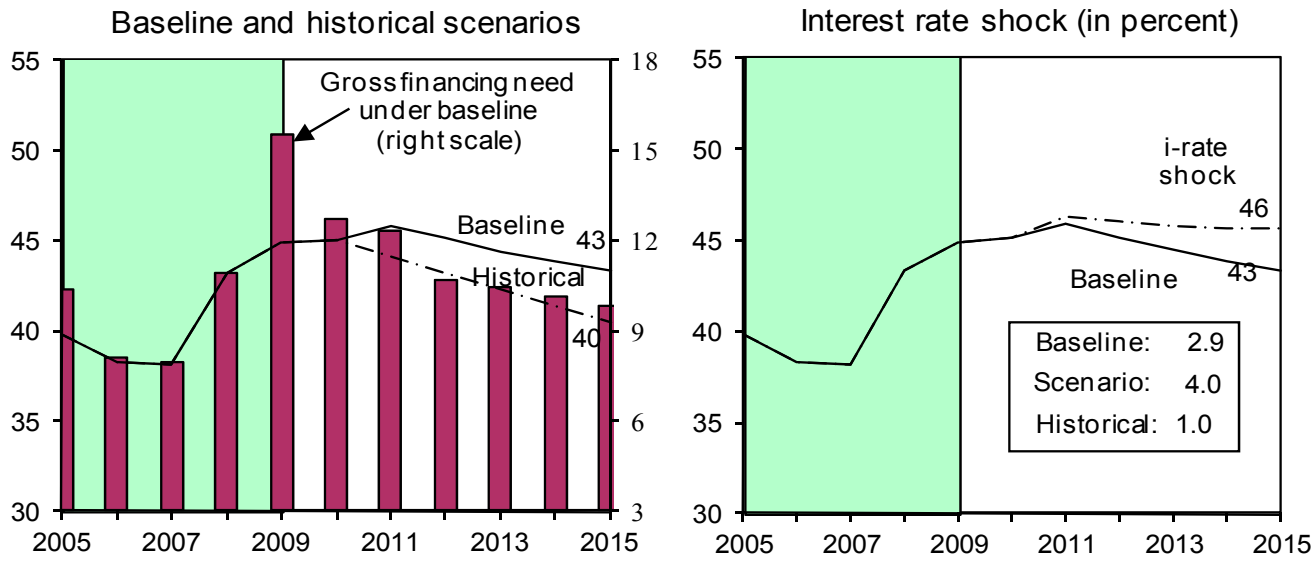

Growth shock (in percent per

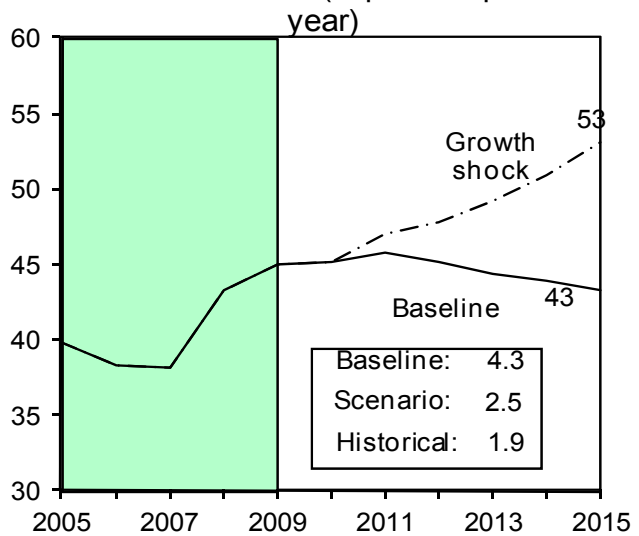

Primary balance shock (in percent of GDP) and no policy change scenario (constant primary balance)

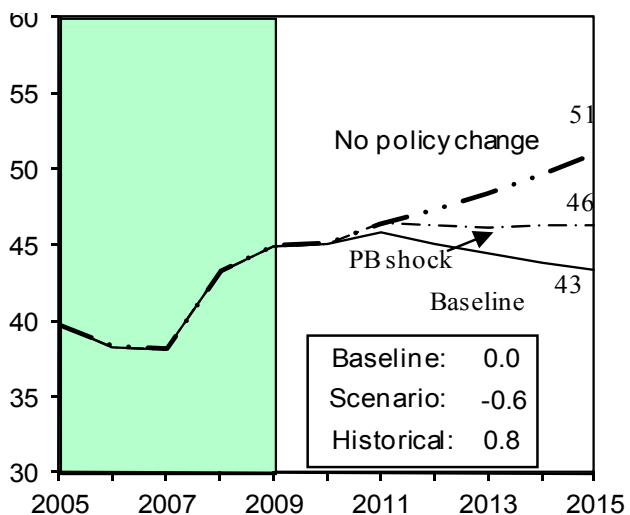

Combined shock 2/

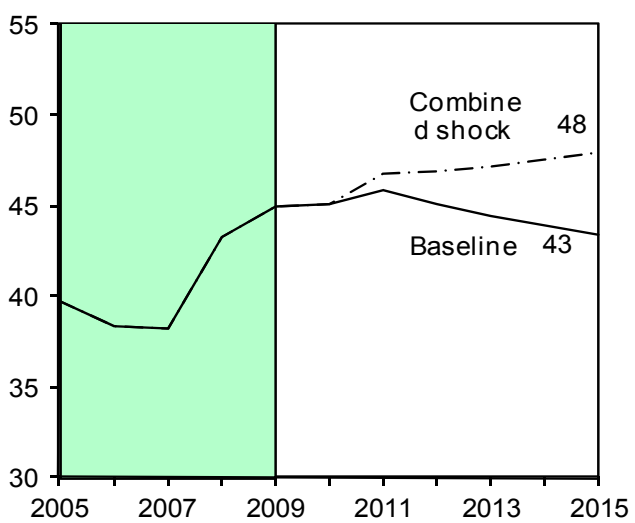

Real depreciation and contingent liabilities shocks $3 /$

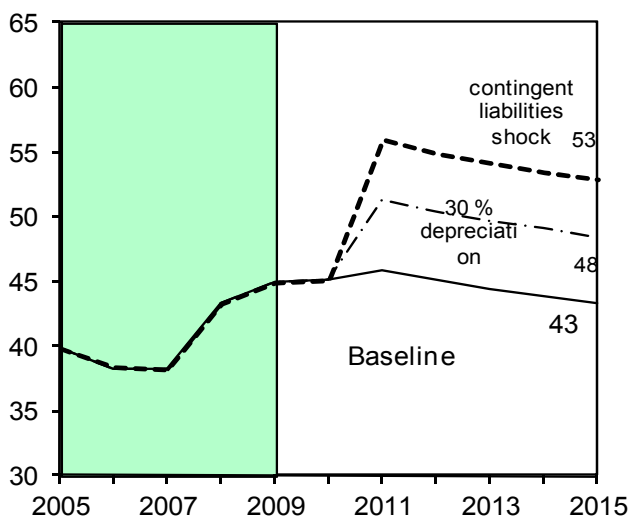

Sources: International Monetary Fund, country desk data, and staff estimates.

1/ Shaded areas rep resent actual data. In dividual shocks are permanent one-half standard deviation shocks.

Figures in the boxes represent average projections for the respective variables in the baseline and scenario being presented. Ten-year historical average for the variable is also shown.

2/ Permanent 1/4 standard deviation shocks ap plied to real interest rate, growth rate, and primary balance.

$3 /$ One-time real depreciation of 30 percent and 10 percent of GDP shock to contingent liabilities occur in 2010 ,

with real depreciation defined as nominal depreciation (measured by percentage fall in dollar value of local

curren cy) minus domestic inflation (based on GDP deflator). 
Absence of systemic bank solvency problems that pose an immediate threat of a banking crisis. Mexico's banking system remains liquid and well-capitalized, with financial soundness indicators broadly unchanged since the approval of the FCL arrangement (including a low level of NPLs net of provisions) (Table 8). The recent events in debt markets in Europe have had no effect on Mexico's banking system.

- Effective financial sector supervision. The overall financial sector supervision framework remains strong as described in www.imf.org. The authorities have further strengthened this framework by creating a high level committee to assess systemic risks and macro-financial linkages.

- Data transparency and integrity. The overall quality of Mexican data continues to be good as described in the October 2010 data ROSC update. Mexico remains in observance of the Special Data Dissemination Standards (SDDS).

\section{The authorities' letter (Attachment) highlights their continued commitment to} implementing very strong economic policies. The authorities note that their main priorities remain to support the ongoing recovery, maintain macroeconomic and financial stability, and continue to lay the basis for strong and sustainable medium term growth.

- Monetary and exchange rate policy. Monetary policy will continue to be conducted under the inflation targeting framework. Against the background of a still-large output gap, fiscal policy geared toward consolidation, and contained price pressures, the authorities have been appropriately maintaining an accommodative monetary stance. Inflation expectations continue to be well anchored by the inflation targeting regime, which will be further strengthened by the planned efforts to continue improving policy communications in line with international best practice. The authorities remain committed to the flexible exchange rate regime, which has served as an important shock absorber during the crisis.

- $\quad$ Fiscal policy remains guided by the balanced budget rule and medium-term budgetary framework. Fiscal consolidation is underway, with significant stimulus being withdrawn in 2010 and non-oil tax revenues strengthened by the major 2010 tax reform. The 2011 budget continues the fiscal consolidation process, and is broadly consistent with the plan of reducing the deficit to zero under the balanced budget rule target by 2012. These steps should serve to gradually bring down public debt as a share of GDP over the next several years.

- $\quad$ Financial stability. The authorities continue to monitor closely financial developments and have been undertaking periodic stress tests to detect various possible risks to the financial system. The results have confirmed consistently the robustness of Mexico's financial system. As anticipated in www.imf.org. the financial sector policy framework has been further strengthened by the establishment of a high level committee to assess systemic risks and macro-financial linkages. 
- External insurance. As earlier indicated, the authorities intend to gradually increase external insurance. They plan to continue to seek to achieve this through a combination of retaining public sector foreign exchange receipts - mainly from PEMEX - and a rules-based intervention mechanism consistent with the context of the freely floating exchange regime. The authorities have also commented that the enhanced FCL acts as an increasingly closer substitute for self-insuring against external risks, and will be a consideration in their reserves strategy going forward.

\section{IMPACT ON FUND FINANCES, RISKS, AND SAFEgUARDS}

\section{Access under the proposed FCL for Mexico of 1,500 percent of quota (SDR} 47.292 billion) is large, but the impact on Fund liquidity and the risks to the Fund are manageable. The Fund's liquidity is expected to remain adequate after the approval of the FCL arrangement for Mexico, as further discussed in the supplement assessing the impact on the Fund's finances and liquidity position.

\section{Notwithstanding the large size of the commitment, the risks to the Fund are judged}

to be low. The authorities have given clear indications that they intend to treat the arrangement as precautionary. Even if a full drawing under the arrangement were to be made on approval, Mexico's external debt would remain moderate at about 21 percent of GDP in 2015, when debt service peaks (Table 7). Further, as the Text Figure shows, even peak debt service ratios would be broadly in line with those in recent years, and remain well within the range seen in other emerging market countries. Moreover, Mexico has a demonstrated excellent track record of meeting its obligations to the Fund.

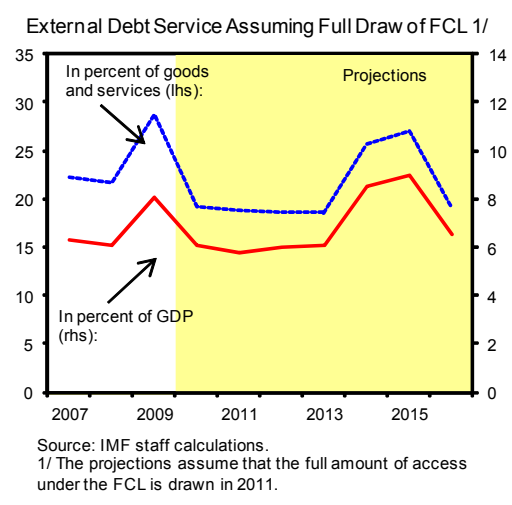

\section{Staff completed the safeguard assessment procedures applicable to FCL}

arrangements for the current FCL approved in March 2010. Under these procedures, staff reviews the most recently completed independent external audit of the member's central bank. An authorization for staff to communicate directly with Banxico's external auditor, PricewaterhouseCoopers $(\mathrm{PwC})$ Mexico, has been provided by the authorities. Staff has reviewed the audited information provided by $\mathrm{PwC}$ for 2009 and discussed the results of the audit with the audit partner on July 8, 2010. No significant safeguards issues emerged. PwC signed an unqualified audit opinion on Banxico's 2009 financial statements in March 2010. Staff will proceed with additional steps required for Mexico's new FCL request, under the safeguards policy for FCLs. 


\section{Staff Appraisal}

23. The staff assesses that Mexico meets the qualification criteria for access to FCL resources. Mexico has very strong policy frameworks and economic fundamentals. The authorities have also demonstrated a sustained track record of excellent policy implementation. They have reacted flexibly and appropriately in response to the effects on Mexico of the global financial crisis and have continued taking important steps to address medium-term challenges.

\section{The staff recommends approval of an FCL arrangement for Mexico of}

SDR 47.292 billion for a period of 24 months. Overall global risks have increased since the approval of the previous FCL arrangement in March 2010, and proven to be more persistent than envisaged in early 2009. Meanwhile, the room for policy maneuver at the international level, in the face of additional unanticipated shocks, is also now much reduced (reflecting especially more limited fiscal space). These considerations continue to raise tail risks for Mexico in the context of its large and open capital markets. As such, a longer duration and higher access successor FCL arrangement would appropriately bolster Mexico's external buffers and continue to support the authorities' policy strategy.

25. The staff judges the risks to the Fund arising from any potential drawing under the proposed FCL arrangement as low. The authorities have an excellent policy implementation track record. Their letter reaffirms their commitment to maintain Mexico's very strong policy frameworks and take needed actions to manage unforeseen risks. Together, these provide a strong assurance that the authorities would react appropriately to any future balance of payments difficulties. Risks to the Fund are further contained by the authorities' intent to treat the FCL arrangement as precautionary, Mexico's very strong repurchase record with the Fund, as well as the manageable external debt service profile even were the full amount of the FCL be drawn up-front. 
Table 1. Mexico: Selected Economic, Financial, and Social Indicators, 2007-2011

I. Social and Demographic Indicators

GDP per capita (U.S. dollars, 2008) Population (millions, 2008)

Lite expectancy at birth (years, 2008)

Under $\zeta$ mortality rate (per thousand, 2008)
10,232 Households below the poverty line (percent, 2002)

106.4 Income share of highest 20 percent / low est 20 percent

15.1 Adult iliteracy rate (2008)

$1 / .5$ Gross primary education enrollment rate (200/)

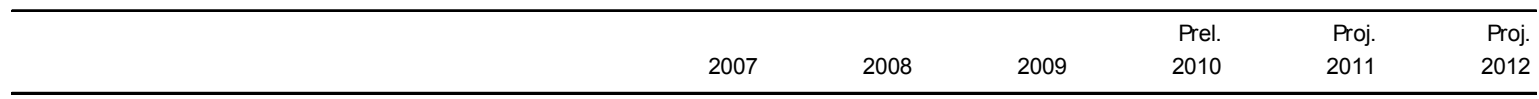

(Annual percentage change, unless otherw ise indıcated)

\section{National accounts in constant prices}

\section{Real GDP}

Net exports (contribution)

Total domestic demand

Private consumption

Public consumption

Gross fixed investment

Change in business inventories (contribution)

\section{External sector}

Exports, f.o.b.

Export volume

Imports, f.o.b.

Import volume

Petroleum exports (percent of total exports)

Terms of trade (deterioration -)

\section{Exchange rates}

Nominal exchange rate (US\$/Mex\$)

(average, depreciation -)

Real effective exchange rate (CPI based)

(average, depreciation -)

\section{Employment and inflation}

Consumer prices (endof year)

Formal sector employment(annual average)

Formal sector unemployment rate (annual average)

Real manufacturing wages (annual average)

Money and credit

Broadmoney (Ma)

Treasury bill rate (28-day cetes, in percent, annual average

\section{Nonfinancial public sector}

Augmented balance 1/

Augmented primary balance

Traditional balance 2/

Gross public sector debt

Net public sector debt

Savings andinvestment

Gross domestic investment

Public investment

Private investment

Change in inventories

Gross national saving

Public saving $3 /$

Private saving

External current account balance

Non-oil external current account balance

Net toreign direct investment

rance

$\begin{array}{rrrrrr}3.3 & 1.5 & -6.5 & 5.0 & 3.9 & 5.0 \\ -0.6 & -0.8 & 1.7 & 1.0 & -0.9 & 0.3 \\ 3.8 & 2.2 & -7.9 & 4.1 & 4.7 & 4.6 \\ 4.0 & 1.9 & -6.1 & 2.7 & 5.1 & 4.8 \\ 3.1 & 0.9 & 2.3 & -0.7 & 3.3 & 6.7 \\ 6.9 & 4.4 & -10.1 & 1.1 & 1.2 & 4.4 \\ -0.7 & -0.1 & -1.9 & 0.9 & 0.7 & -0.3 \\ & & & & & \\ 8.8 & 7.2 & -21.2 & 31.7 & 4.2 & 8.4 \\ 3.5 & -2.4 & -13.4 & 17.4 & 3.2 & -2.5 \\ 10.1 & 9.5 & -24.0 & 31.9 & 6.6 & 9.6 \\ 4.4 & 1.0 & -18.6 & 19.1 & 3.4 & 5.0 \\ 14.9 & 16.4 & 12.6 & 10.9 & 10.3 & 9.6 \\ -0.3 & 1.3 & -2.4 & 1.3 & -2.0 & 6.5\end{array}$

Public external debt service 4/

(In percent ot exports ot goods, nontactor services, and transters)

$\begin{array}{llll}-0.3 & -1.8 & -21.4 & 5.9 \\ -1.1 & -1.6 & -12.5 & 8.1\end{array}$

$\begin{array}{rrrrrr}3.8 & 6.5 & 3.6 & 4.3 & 3.0 & 3.0 \\ 4.2 & 2.1 & -3.1 & \ldots & \ldots & \ldots \\ 3.7 & 4.0 & 5.5 & 5.0 & 4.5 & 3.9 \\ -0.7 & 0.2 & 1.3 & \ldots & \ldots & \ldots \\ & & & & & \\ 11.5 & 11.9 & 7.0 & 11.3 & & \end{array}$

$\begin{array}{rr}11.5 & 11 \\ 7.2 & 7.6\end{array}$

(In percent of GDP)

$\begin{array}{rrrrrr}-1.3 & -1.4 & -4.9 & -3.6 & -3.2 & -2.6 \\ 1.4 & 1.1 & -2.1 & -1.6 & -0.6 & 0.1 \\ 0.0 & -0.1 & -2.3 & -2.1 & -2.6 & -2.1 \\ 38.2 & 43.3 & 44.9 & 45.1 & 45.9 & 45.1 \\ 31.4 & 35.1 & 39.1 & 39.5 & 40.6 & 40.2 \\ & & & & & \\ 26.2 & 25.8 & 21.1 & 22.4 & 24.2 & 24.2 \\ 4.3 & 4.7 & 5.1 & 5.8 & 5.7 & 5.2 \\ 16.5 & 16.1 & 16.1 & 16.0 & 15.3 & 15.5 \\ 3.3 & 4.5 & 5.2 & 0.6 & 3.1 & 3.5 \\ 25.1 & 25.0 & 25.1 & 21.8 & 23.0 & 22.8 \\ 3.7 & 3.3 & 3.3 & 0.4 & 1.6 & 1.7 \\ 22.0 & 21.7 & 22.3 & 21.4 & 21.4 & 21.0 \\ -0.8 & -1.5 & -0.7 & -1.2 & -1.4 & -1.5 \\ -2.7 & -3.0 & -1.8 & -1.8 & -1.4 & -1.0 \\ 1.9 & 2.0 & 0.4 & 1.5 & 1.8 & 1.8\end{array}$
7.5
6.8
6.7
5.5
6.9
6.0

(In billions of U.S. dollars, unless otherw ise indicated)

Net international reserves

Gross official reserves in percent of broad money

Gross external debt (in percent of GDP, end of period)

Crude oll export price, Mexican mix (US\$/bbl)

$\begin{array}{lll}78.0 & 85.4 & 90.8 \\ 16.7 & 16.4 & 17.8 \\ 18.8 & 18.5 & 23.6\end{array}$

$\begin{array}{ll}16.7 & 16.4 \\ 18.8 & 18.5\end{array}$

61.7

84.4

90.8
17.8
23.6

23.6
57.6

$\begin{array}{rrr}113.8 & 123.8 & 133.8 \\ 17.6 & 17.3 & 17.6 \\ 24.2 & 24.5 & 24.2 \\ 71.3 & 72.1 & 73.1\end{array}$

Sources:National Institute of Statistics and Geography; Bank of Mexico; Secretariat of Finance and Public Credit; and IMF staff estimates.

1/ Public Sector Borrow ing Kequirements excl. nonrecurrent revenue.

2/ The break in the series in 2009 is due to definitional and accounting changes.

3 / Estimated as as the difference betw een the augmented fiscal balance, as reported by SHCP, and public investment, as reported in the national accounts. 4 / Debt service on gross external debt ot the tederal government, development banks and nontinanical public enterprises (adjusted tor Hdiregas). 
Table 2. Mexico: Financial Operations of the Public Sector, 2007-2015 (In percent of GDP)

\begin{tabular}{|c|c|c|c|c|c|c|c|c|c|c|c|}
\hline & \multirow[t]{2}{*}{2007} & \multirow[t]{2}{*}{2008} & \multirow[t]{2}{*}{2009} & \multicolumn{2}{|c|}{2010} & \multicolumn{2}{|c|}{2011} & \multirow{2}{*}{$\begin{array}{r}2012 \\
\text { Proj. }\end{array}$} & \multirow{2}{*}{$\begin{array}{c}2013 \\
\text { Proj. }\end{array}$} & \multirow{2}{*}{$\begin{array}{c}2014 \\
\text { Proj. }\end{array}$} & \multirow{2}{*}{$\begin{array}{r}2015 \\
\text { Proj. }\end{array}$} \\
\hline & & & & Budget & Proj. & Budget & Proj. & & & & \\
\hline Budgetary revenue, by type & 22.2 & 23.6 & 23.8 & 21.9 & 22.5 & 22.3 & 22.3 & 22.3 & 22.2 & 21.9 & 21.6 \\
\hline Oil revenue & 7.9 & 8.7 & 7.9 & 7.1 & 7.3 & 7.3 & 7.4 & 7.0 & 7.0 & 6.8 & 6.6 \\
\hline Non-oil tax revenue $1 /$ & 9.3 & 10.0 & 9.5 & 10.3 & 10.5 & 10.7 & 10.6 & 11.1 & 11.0 & 10.9 & 10.7 \\
\hline Non-oil non-tax revenue & 5.0 & 4.9 & 6.4 & 4.4 & 4.7 & 4.2 & 4.2 & 4.2 & 4.2 & 4.2 & 4.2 \\
\hline \multicolumn{12}{|l|}{ Budgetary revenue, by entity } \\
\hline Federal government revenue & 15.3 & 16.9 & 16.9 & 15.6 & 14.7 & 15.9 & 14.4 & 14.5 & 14.4 & 14.2 & 14.1 \\
\hline Tax revenue, of which: & 8.9 & 8.2 & 9.6 & 10.2 & 10.1 & 10.7 & 10.4 & 10.9 & 10.9 & 11.0 & 11.0 \\
\hline excises (including fuel) & -0.1 & -1.4 & 0.4 & 0.4 & 0.1 & 0.5 & 0.3 & 0.3 & 0.4 & 0.5 & 0.7 \\
\hline Nontax revenue & 6.3 & 8.7 & 7.4 & 5.3 & 4.6 & 5.2 & 4.0 & 3.6 & 3.4 & 3.2 & 3.1 \\
\hline Public enterprises & 6.9 & 6.7 & 6.9 & 6.3 & 7.9 & 6.4 & 7.9 & 7.8 & 7.8 & 7.7 & 7.6 \\
\hline PEMEX & 3.3 & 3.0 & 3.2 & 2.8 & 4.3 & 2.8 & 4.3 & 4.3 & 4.3 & 4.1 & 4.0 \\
\hline Other & 3.6 & 3.7 & 3.7 & 3.5 & 3.6 & 3.6 & 3.6 & 3.6 & 3.6 & 3.6 & 3.6 \\
\hline Budgetary expenditure & 22.1 & 23.7 & 26.1 & 24.6 & 25.3 & 24.9 & 24.9 & 24.4 & 24.2 & 23.8 & 23.4 \\
\hline Primary & 20.0 & 21.8 & 23.9 & 22.3 & 23.7 & 22.6 & 22.6 & 22.0 & 21.8 & 21.4 & 21.1 \\
\hline Programmable & 16.9 & 18.2 & 20.6 & 18.8 & 19.9 & 18.8 & 18.9 & 18.3 & 18.1 & 17.8 & 17.5 \\
\hline Current & 13.3 & 13.8 & 15.5 & 14.2 & 14.5 & 14.0 & 14.0 & 13.8 & 13.6 & 13.5 & 13.4 \\
\hline Wages & 5.8 & 5.9 & 6.5 & 6.3 & 6.2 & 6.2 & 6.2 & 5.9 & 5.7 & 5.6 & 5.4 \\
\hline Pensions & 2.1 & 2.1 & 2.4 & 2.4 & 2.5 & 2.4 & 2.4 & 2.5 & 2.7 & 2.9 & 3.0 \\
\hline Subsidies and transfers & 2.3 & 2.7 & 3.1 & 2.9 & 2.8 & 2.7 & 2.7 & 2.7 & 2.7 & 2.7 & 2.7 \\
\hline Other & 3.1 & 3.2 & 3.4 & 2.6 & 3.1 & 2.7 & 2.7 & 2.6 & 2.5 & 2.3 & 2.2 \\
\hline Capital & 3.6 & 4.4 & 5.1 & 4.6 & 5.4 & 4.8 & 4.8 & 4.5 & 4.5 & 4.3 & 4.0 \\
\hline Physical capital & 2.8 & 3.1 & 4.6 & 4.5 & 5.2 & 4.7 & 4.8 & 4.3 & 4.4 & 4.1 & 3.9 \\
\hline Of which: non Pemex & 2.5 & 2.5 & 2.5 & 2.4 & 3.2 & 2.6 & 2.7 & 2.2 & 2.4 & 2.2 & 2.1 \\
\hline Financial capital & 0.8 & 1.3 & 0.5 & 0.1 & 0.2 & 0.1 & 0.0 & 0.1 & 0.1 & 0.1 & 0.1 \\
\hline Nonprogrammable & 3.1 & 3.6 & 3.3 & 3.6 & 3.8 & 3.7 & 3.7 & 3.7 & 3.7 & 3.7 & 3.6 \\
\hline Of which: revenue sharing & 3.0 & 3.5 & 3.2 & 3.5 & 3.6 & 3.6 & 3.6 & 3.6 & 3.6 & 3.5 & 3.5 \\
\hline Interest payments $2 /$ & 2.1 & 1.9 & 2.2 & 2.3 & 1.6 & 2.3 & 2.3 & 2.4 & 2.3 & 2.3 & 2.3 \\
\hline Traditional balance $3 /$ & 0.0 & -0.1 & -2.3 & -2.8 & -2.7 & -2.6 & -2.6 & -2.1 & -2.0 & -1.9 & -1.8 \\
\hline Traditional balance for balanced budget rule & 0.0 & -0.1 & -0.2 & -0.7 & -0.7 & -0.5 & -0.5 & 0.0 & 0.0 & 0.0 & 0.0 \\
\hline Adjustments to the traditional balance & 1.4 & 1.3 & 2.6 & 1.3 & 0.8 & 0.9 & 0.6 & 0.5 & 0.5 & 0.5 & 0.5 \\
\hline PIDIREGAS & 0.9 & 1.1 & 0.0 & 0.1 & 0.1 & 0.1 & 0.1 & 0.1 & 0.1 & 0.1 & 0.1 \\
\hline IPAB & 0.1 & 0.2 & 0.1 & 0.2 & 0.2 & 0.2 & 0.1 & 0.1 & 0.1 & 0.1 & 0.1 \\
\hline Budgetary adjustments & 0.4 & 0.3 & 0.3 & 0.3 & 0.3 & 0.3 & 0.2 & 0.2 & 0.1 & 0.1 & 0.1 \\
\hline PEMEX, oil stabilization fund, FARP (-: net inflow s) & -0.4 & -1.0 & 0.7 & 0.3 & -0.2 & 0.0 & 0.0 & -0.1 & -0.1 & -0.1 & -0.1 \\
\hline FARAC/FONADIN & -0.2 & 0.0 & 0.0 & 0.0 & 0.0 & 0.0 & 0.0 & 0.0 & 0.0 & 0.0 & 0.0 \\
\hline Debtor support & 0.0 & 0.0 & 0.0 & 0.0 & 0.0 & 0.0 & 0.0 & 0.0 & 0.0 & 0.0 & 0.0 \\
\hline Development banks (changes in capital) & -0.1 & -0.1 & -0.1 & 0.0 & -0.1 & 0.0 & -0.1 & -0.1 & -0.1 & -0.1 & -0.1 \\
\hline Nonrecurring revenue & 0.6 & 0.7 & 1.6 & 0.4 & 0.5 & 0.5 & 0.3 & 0.3 & 0.3 & 0.3 & 0.3 \\
\hline Augmented balance (excl. net lending of dev. banks) 4 / & -1.3 & -1.4 & -4.9 & -4.1 & -3.6 & -3.5 & -3.2 & -2.6 & -2.5 & -2.3 & -2.2 \\
\hline Augmented interest expenditure & 2.7 & 2.5 & 2.8 & 2.4 & 2.0 & 2.8 & 2.6 & 2.6 & 2.6 & 2.5 & 2.5 \\
\hline Augmented primary balance (excl. dev. Banks) 5/ & 1.4 & 1.1 & -2.1 & -1.6 & -1.6 & -0.7 & -0.6 & 0.1 & 0.1 & 0.2 & 0.3 \\
\hline \multicolumn{12}{|l|}{ Memorandum items } \\
\hline Crude oil export price, Mexican mix (US\$/bbl) & 61.7 & 84.4 & 57.8 & 59.0 & 71.3 & 65.4 & 72.1 & 73.1 & 75.4 & 76.5 & 77.8 \\
\hline Development banks & 0.0 & 0.4 & 0.5 & 0.5 & 0.5 & 0.4 & 0.4 & 0.3 & 0.3 & 0.3 & 0.3 \\
\hline Augmented balance (incl. net lending of dev. banks) 4 / & -1.4 & -1.8 & -5.5 & -4.5 & -4.1 & -4.0 & -3.7 & -3.0 & -2.9 & -2.8 & -2.6 \\
\hline Augmented primary balance (incl. net lending of dev. Banks)! & 1.2 & 0.7 & -2.7 & -2.1 & -2.2 & -1.2 & -1.1 & -0.4 & -0.3 & -0.2 & -0.1 \\
\hline Non-oil augmented balance $6 /$ & -6.5 & -7.5 & -9.8 & $\ldots$ & -7.9 & $\ldots$ & -7.6 & -6.4 & -6.3 & -6.2 & -6.0 \\
\hline Oil augmented balance & 5.0 & 5.7 & 4.4 & $\ldots$ & 3.8 & $\ldots$ & 3.9 & 3.4 & 3.5 & 3.4 & 3.4 \\
\hline Oil-related expenditure & 2.8 & 3.0 & 3.6 & $\ldots$ & 3.5 & $\ldots$ & 3.6 & 3.6 & 3.5 & 3.4 & 3.3 \\
\hline Gross public sector debt & 38.2 & 43.3 & 44.9 & $\ldots$ & 45.1 & $\ldots$ & 45.9 & 45.1 & 44.4 & 43.9 & 43.4 \\
\hline Domestic (percentage of total debt) & 73.0 & 70.3 & 73.0 & $\ldots$ & 75.9 & $\ldots$ & 77.7 & 79.2 & 80.4 & 81.6 & 82.6 \\
\hline External (percentage of total debt) & 27.0 & 29.7 & 27.0 & $\ldots$ & 24.1 & $\ldots$ & 22.3 & 20.8 & 19.6 & 18.4 & 17.4 \\
\hline Net public sector debt & 31.4 & 35.7 & 39.1 & $\ldots$ & 39.5 & $\ldots$ & 40.6 & 40.2 & 39.7 & 39.4 & 39.0 \\
\hline Nominal GDP (billions of Mexican pesos) & 11,208 & 12,130 & 11,822 & 12,793 & 12,870 & 13,723 & 13,723 & 14,907 & 16,136 & 17,378 & 18,669 \\
\hline
\end{tabular}

Sources: Mexican authorities; and IMF staff estimates. Data refer to non-financial public sector, including PEMEX and other public enterprises but excluding state and local governments (except as noted).

$1 /$ Total tax revenue excluding excise tax on gasoline.

$2 /$ Includes transfers to IPAB and the debtor support programs.

$3 /$ I he break in the series in $200 y$ is due to detinitional and accounting changes.

4/ Public Sector Borrow ing Requirements excl. nonrecurrent revenue.

$5 /$ Treats transfers to IPAB as interest payments.

6/ Excludes oil revenue (oil extraction rights, PEMEX net income, oil excess return levies, excise tax on gasoline) and PEMEX operational expenditure, interest payments, and capital expenditure. 
Table 3. Mexico: Summary Balance of Payments, 2007-15

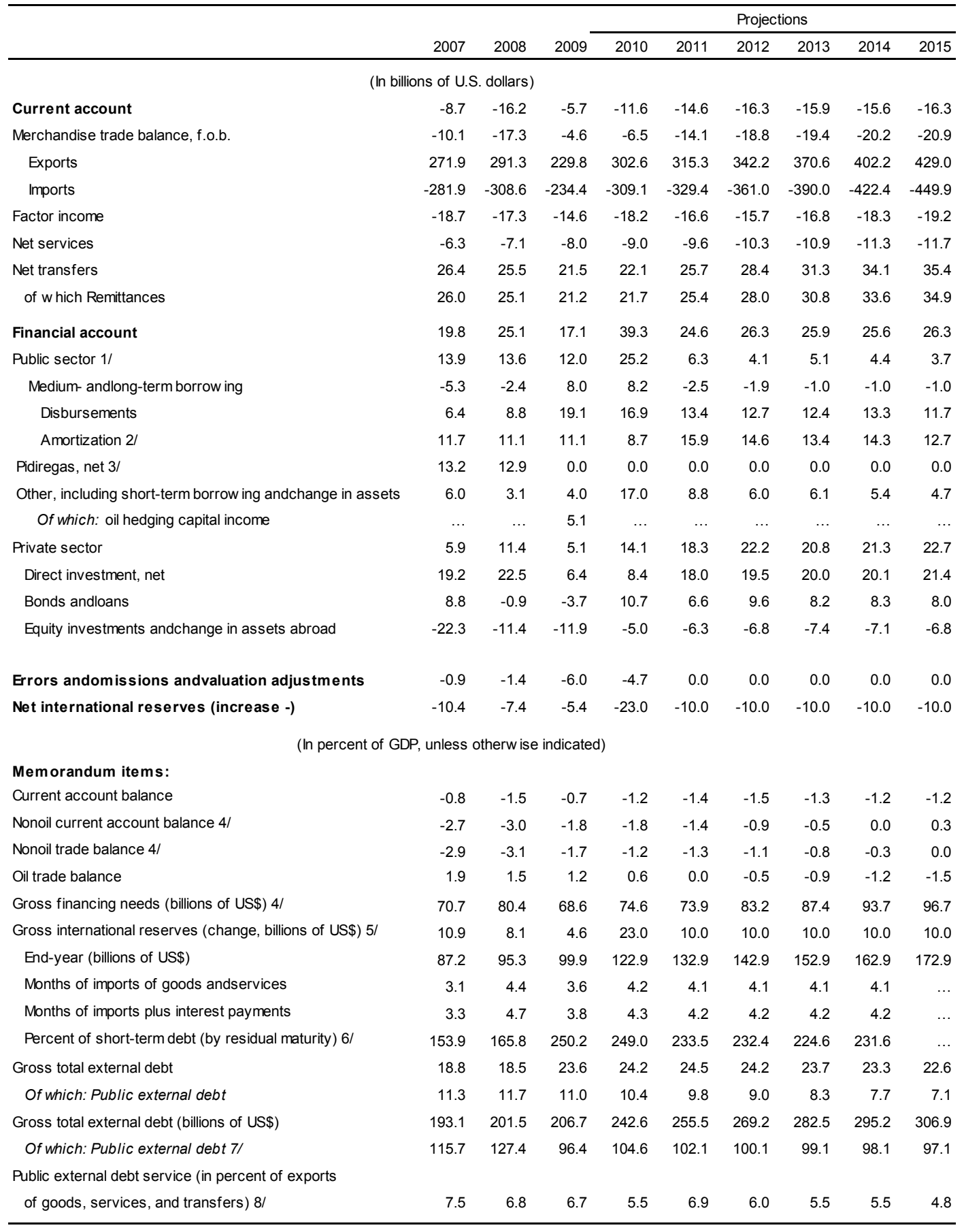

Sources: Bank of Mexico; Secretariat of Finance andPublic Credit; andFundstaff projections.

$1 /$ Including the financing of PIDIREGAS.

2/ Includes pre-payment of external debt.

3/ Break in the series in 2009 due to accounting changes.

4/ Excluding oil exports and petroleum products imports.

5/ Excludes balances under bilateral payments accounts. For 2009, includes the allocation of SDR 2.337 billion in the general allocation implemented on August 28, 2009, and another SDR 0.224 billion in the special allocation on September 9.

$6 /$ In percent of short-term debt by residual maturity. Historical data include all prepayments.

7/ Includes gross external debt of the federal government, development banks andnonfinancial public enterprises, andis adjustedfor PIDIREGAS.

8 / Includes amortization on medium and long-term bonds and debt, and interest payments. 
Table 4. Mexico: External Financing Requirements and Sources, 2007-12

\begin{tabular}{|c|c|c|c|c|c|c|c|c|c|c|}
\hline & 2007 & 2008 & 2009 & $\begin{array}{l}2010 \\
\text { Proj. }\end{array}$ & $\begin{array}{l}2011 \\
\text { Proj. }\end{array}$ & $\begin{array}{c}2011 \\
\text { Adv. scenario }\end{array}$ & $\begin{array}{l}\text { Contribution } \\
\text { to gap }\end{array}$ & $\begin{array}{l}2012 \\
\text { Proj. }\end{array}$ & $\begin{array}{c}2012 \\
\text { Adv. scenario }\end{array}$ & $\begin{array}{l}\text { Contribution } \\
\text { to gap }\end{array}$ \\
\hline Gross financing requirements (A) & 70.7 & 80.4 & 68.6 & 74.6 & 73.9 & 80.4 & & 83.2 & 90.4 & \\
\hline Current account deficit & 8.7 & 16.2 & 5.7 & 11.6 & 14.6 & 21.0 & 6.5 & 16.3 & 23.5 & 7.2 \\
\hline Public sector medium and long term amortization 1/ & 15.2 & 14.4 & 11.1 & 8.7 & 15.9 & 15.9 & & 14.6 & 14.6 & \\
\hline Public sector bonds $2 /$ & 8.8 & 6.9 & 4.9 & 5.5 & 8.2 & 8.2 & & 8.1 & 8.1 & \\
\hline Public sector MLT debt & 2.9 & 4.2 & 6.2 & 3.2 & 7.7 & 7.7 & & 6.5 & 6.5 & \\
\hline PIDIREGAS $3 /$ & 3.5 & 3.2 & 0.0 & 0.0 & 0.0 & 0.0 & & 0.0 & 0.0 & \\
\hline Private sector medium and long term amortization 4/ & 13.9 & 15.5 & 20.6 & 12.3 & 13.4 & 13.4 & & 19.1 & 19.1 & \\
\hline Private sector bonds $4 /$ & 6.0 & 6.7 & 6.0 & 6.7 & 9.4 & 9.4 & & 9.9 & 9.9 & \\
\hline Private sector medium and long term debt $4 /$ & 8.0 & 8.8 & 14.7 & 5.6 & 4.0 & 4.0 & & 9.2 & 9.2 & \\
\hline Short term financing & 22.6 & 26.8 & 25.7 & 18.9 & 20.0 & 20.0 & & 23.2 & 23.2 & \\
\hline Public sector 21 & 7.0 & 9.4 & 7.2 & 2.1 & 2.1 & 2.1 & & 2.1 & 2.1 & \\
\hline Private sector $4 / 5 /$ & 6.2 & 7.1 & 6.9 & 6.0 & 6.6 & 6.6 & & 9.2 & 9.2 & \\
\hline Trade credit 6/ & 9.4 & 10.2 & 11.6 & 10.8 & 11.3 & 11.3 & & 11.9 & 11.9 & \\
\hline Change in international reserves & 10.3 & 7.5 & 5.4 & 23.0 & 10.0 & 10.0 & & 10.0 & 10.0 & \\
\hline Available financing (B) & 70.7 & 80.4 & 68.6 & 74.6 & 73.9 & 45.1 & & 83.2 & 45.9 & \\
\hline FDI, net & 19.2 & 22.5 & 6.4 & 8.4 & 18.0 & 11.5 & 6.5 & 19.5 & 11.3 & 8.2 \\
\hline Public sector MLT flows $1 /$ & 23.1 & 24.9 & 19.1 & 16.9 & 13.4 & 13.4 & 0.0 & 12.7 & 12.7 & 0.0 \\
\hline Public sector bonds $2 /$ & 3.1 & 2.2 & 10.7 & 8.5 & 5.7 & 5.7 & & 6.2 & 6.2 & \\
\hline Public sector MLT debt & 3.3 & 6.5 & 8.4 & 8.4 & 7.7 & 7.7 & & 6.5 & 6.5 & \\
\hline PIDIREGAS 3/ & 16.7 & 16.1 & 0.0 & 0.0 & 0.0 & 0.0 & & 0.0 & 0.0 & \\
\hline Net change in nonresidents' holdings of peso denominated debt & 7.8 & 6.0 & 3.5 & 17.0 & 8.8 & 4.3 & 4.5 & 6.0 & 0.5 & 5.6 \\
\hline Private sector MLT flows 4/ & 21.0 & 13.4 & 18.7 & 22.4 & 17.5 & 10.9 & 6.6 & 25.4 & 15.5 & 9.9 \\
\hline Private sector bonds & 9.0 & 4.1 & 8.0 & 15.8 & 11.0 & 6.9 & & 12.7 & 7.8 & \\
\hline Private sector MLT debt & 12.0 & 9.3 & 10.6 & 6.6 & 6.4 & 4.0 & & 12.7 & 7.7 & \\
\hline Short-term financing & 22.5 & 25.2 & 24.5 & 20.0 & 23.2 & 16.4 & 6.8 & 27.1 & 18.9 & 8.2 \\
\hline Public sector 2l & 5.2 & 6.6 & 7.7 & 2.1 & 2.1 & 2.1 & & 2.1 & 2.1 & \\
\hline Private sector $4 / 5 /$ & 7.1 & 6.9 & 6.0 & 6.6 & 9.2 & 4.7 & & 12.5 & 7.1 & \\
\hline Trade credit 6/ & 10.2 & 11.6 & 10.8 & 11.3 & 11.9 & 9.6 & & 12.5 & 9.8 & \\
\hline Other flows & -22.9 & -11.5 & -3.6 & -10.2 & -6.9 & -11.4 & 4.5 & -7.4 & -13.1 & 5.7 \\
\hline of which: & & & & & & & & & & \\
\hline Increase in portfolio and other investment assets & -21.8 & -7.9 & -11.0 & -9.0 & -10.5 & -15.0 & & -11.3 & -16.9 & \\
\hline $\begin{array}{l}\text { of which: In banks abroad } \\
\text { Oil price hedge }\end{array}$ & -17.0 & -2.7 & $\begin{array}{r}-4.8 \\
5.1\end{array}$ & -5.0 & -6.3 & -9.0 & & -7.2 & -10.8 & \\
\hline Financing Gap (B-A) 7 & 00 & 00 & 00 & 00 & 00 & -353 & 353 & & -446 & 446 \\
\hline
\end{tabular}

Sources: Mexican authorities and IMF staff estimates.

1/ Including PIDIREGAS.

2/ On a BoP basis.

$3 /$ Includes bonds and loans. For 2006-08, staff estimates based on the stock of debt at original maturity, estimated

wer

estimated duration, and net financing data from the Balance of Payments.

$5 /$ Loans and money market instruments, estimates on original maturity basis.

6/ Includes accounts payable to suppliers and long-term trade credit.
$7 /$ The adverse scenario applies independent shocks in 2011 and in 2012 to generate a risk envolope; thus the gaps in 2011 and 2012 should not be added together 
Table 5. Mexico: External Debt Sustainability Framework, 2005-15

(In percent of GDP, unless otherwise indicated)

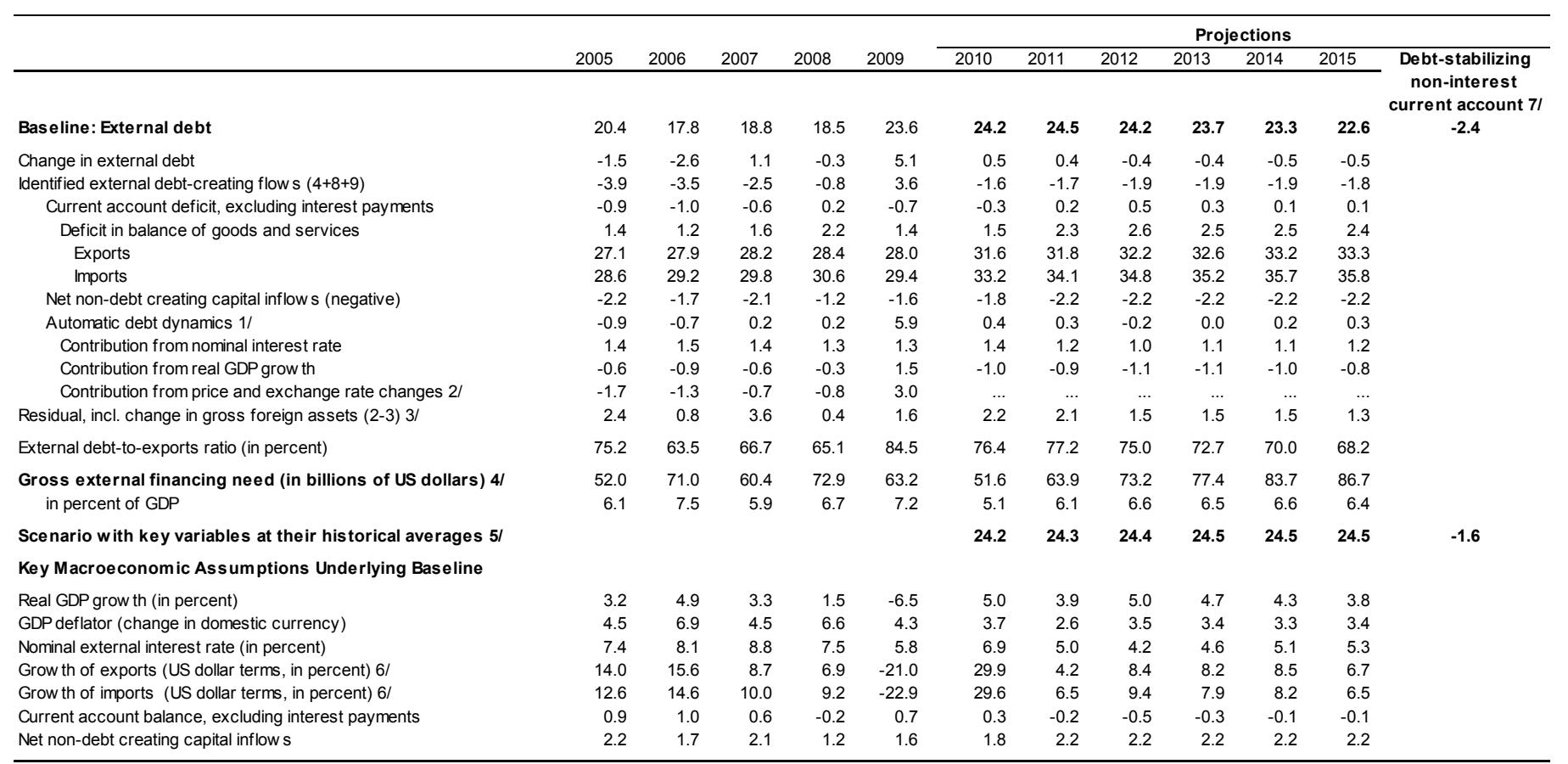

$1 /$ Derived as $[r-g-r(1+g)+e a(1+r)] /(1+g+r+g r)$ times previous period debt stock, $w$ ith $r=$ nominal effective interest rate on external debt; $r=$ change in domestic GDP deflator in US dollar terms,

$\mathrm{g}=$ real GDP grow th rate, $\mathrm{e}=$ nominal appreciation (increase in dollar value of domestic currency), and $\mathrm{a}=$ share of domestic-currency denominated debt in total external debt.

$2 /$ The contribution from price and exchange rate changes is defined as $[-r(1+g)+e a(1+r)](1+g+r+g r)$ times previous period debt stock. $r$ increases with an appreciating domestic currency $(e>0)$ and rising inflation (based on GDP deflator).

$3 /$ For projection, line includes the impact of price and exchange rate changes.

4/ Defined as current account deficit, plus amortization on medium- and long-term debt, plus short-term debt at end of previous period.

$5 /$ The key variables include real GDP grow th; nominal interest rate; dollar deflator grow th; and both non-interest current account and non-debt inflow s in percent of GDP.

6/ Goods and nonfactor services.

7/ Long-run, constant balance that stabilizes the debt ratio assuming that key variables (real GDP grow th, nominal interest rate, dollar deflator grow th, and non-debt inflow s in percent of GDP) remain at their levels of the last projection year. 
Table 6. Mexico: Gross Public Sector Debt Sustainability Framework, 2005-2015

(In percent of GDP, unless otherwise indicated)

\begin{tabular}{|c|c|c|c|c|c|c|c|c|c|c|c|c|}
\hline & \multirow[b]{2}{*}{2005} & \multirow[b]{2}{*}{2006} & \multirow[b]{2}{*}{2007} & \multirow[b]{2}{*}{2008} & \multirow[b]{2}{*}{2009} & \multicolumn{6}{|c|}{ Projections } & \multirow{3}{*}{$\begin{array}{c}\text { Debt-stabilizing } \\
\text { primary } \\
\text { balance } 9 /\end{array}$} \\
\hline & & & & & & 2010 & 2011 & 2012 & 2013 & 2014 & 2015 & \\
\hline & & & & & & & & & & & & \\
\hline $\begin{array}{l}\text { Base line: Gross public sector de bt } 1 / \\
\text { o/w foreign-currency denominated } 7 /\end{array}$ & $\begin{array}{l}39.8 \\
12.8\end{array}$ & $\begin{array}{l}38.3 \\
10.2\end{array}$ & $\begin{array}{l}38.2 \\
10.3\end{array}$ & $\begin{array}{l}43.3 \\
12.9\end{array}$ & $\begin{array}{l}44.9 \\
12.1\end{array}$ & $\begin{array}{l}45.1 \\
10.9\end{array}$ & $\begin{array}{l}45.9 \\
103\end{array}$ & $\begin{array}{r}45.1 \\
94\end{array}$ & $\begin{array}{r}44.4 \\
87\end{array}$ & $\begin{array}{r}43.9 \\
81\end{array}$ & $\begin{array}{r}43.4 \\
7.5\end{array}$ & -0.8 \\
\hline Change in gross public sector debt & -1.6 & -1.5 & -0.1 & 5.1 & 1.7 & 0.2 & 0.8 & -0.7 & -0.7 & -0.5 & -0.5 & \\
\hline Identified debt-creating flows $(4+7+12)$ & -2.5 & -3.4 & -2.1 & 0.5 & 3.7 & -0.6 & 0.3 & -1.3 & -1.2 & -1.1 & -1.1 & \\
\hline Primary deficit & -1.5 & -1.7 & -1.4 & -1.3 & 2.3 & 1.6 & 0.6 & -0.1 & -0.1 & -0.2 & -0.3 & \\
\hline Revenue and grants & 20.8 & 21.4 & 21.4 & 22.9 & 22.2 & 21.9 & 21.9 & 21.9 & 21.8 & 21.5 & 21.3 & \\
\hline Primary (noninterest) expenditure & 19.3 & 19.7 & 20.1 & 21.5 & 24.5 & 23.5 & 22.6 & 21.8 & 21.7 & 21.3 & 21.0 & \\
\hline Automatic debt dynamics $2 /$ & -0.8 & -1.4 & -0.1 & 2.6 & 3.0 & -1.7 & 0.0 & -0.9 & -0.7 & -0.5 & -0.4 & \\
\hline Contribution from interest rate/grow th differential $3 /$ & -0.1 & -1.6 & -0.2 & -0.2 & 3.7 & -1.7 & -0.2 & -1.0 & -0.9 & -0.6 & -0.5 & \\
\hline Of which: contribution from real interest rate & 1.1 & 0.2 & 1.0 & 0.3 & 0.8 & 0.4 & 1.5 & 1.1 & 1.1 & 1.1 & 1.1 & \\
\hline Of which contribution from real GDP grow th & -1.2 & -1.8 & -1.2 & -0.5 & 2.9 & -2.1 & -1.7 & -2.1 & -1.9 & -1.8 & -1.6 & \\
\hline Contribution from exchange rate depreciation $4 /$ & -0.7 & 0.2 & 0.1 & 2.8 & -0.8 & 0.0 & 0.2 & 0.1 & 0.1 & 0.1 & 0.1 & \\
\hline Other identified debt-creating flows & -0.2 & -0.3 & $\begin{array}{l}0.1 \\
-0.6\end{array}$ & -0.7 & -1.6 & -0.5 & -0.3 & -0.3 & -0.3 & -0.3 & -0.3 & \\
\hline Privatization receipts (negative) & -0.2 & -0.3 & -0.6 & -0.7 & -1.6 & -0.5 & -0.3 & -0.3 & -0.3 & -0.3 & -0.3 & \\
\hline Recognition of implicit or contingent liabilities & 0.0 & 0.0 & 0.0 & 0.0 & 0.0 & 0.0 & 0.0 & 0.0 & 0.0 & 0.0 & 0.0 & \\
\hline Other (specify, e.g. bank recapitalization) & 0.0 & 0.0 & 0.0 & 0.0 & 0.0 & 0.0 & 0.0 & 0.0 & 0.0 & 0.0 & 0.0 & \\
\hline Residual, including asset changes (2-3) $5 /$ & 0.9 & 1.9 & 1.9 & 4.6 & -2.0 & 0.7 & 0.5 & 0.5 & 0.5 & 0.5 & 0.5 & \\
\hline Gross public sector debt-to-revenue ratio $1 /$ & 191.3 & 179.1 & 178.4 & 189.3 & 202.1 & 206.0 & 209.0 & 206.0 & 203.4 & 203.9 & 203.8 & \\
\hline Gross financing need $6 /$ & 10.4 & 8.1 & 8.0 & 10.9 & 15.5 & 12.7 & 12.4 & 10.7 & 10.5 & 10.1 & 9.8 & \\
\hline in billions of U.S. dollars & 88.1 & 77.5 & 82.0 & 119.2 & 136.0 & 127.6 & 128.8 & 118.8 & 124.7 & 128.4 & 132.1 & \\
\hline Scenario with key variables at the ir historical averages 71 & & & & & & 45.1 & 44.1 & 43.2 & 42.3 & 41.4 & 40.4 & -0.7 \\
\hline Scenario with no policy change (constant primary balance) in $2010-2015$ & & & & & & 45.1 & 46.4 & 47.4 & 49.1 & 51.2 & 53.5 & 0.1 \\
\hline \multicolumn{13}{|l|}{ Key Macroeconomic and Fiscal Assumptions Underlying Baseline } \\
\hline Real GDP grow th (in percent) & 3.2 & 4.9 & 3.3 & 1.5 & -6.5 & 5.0 & 3.9 & 5.0 & 4.7 & 4.3 & 3.8 & \\
\hline Average nominal interest rate on public debt (in percent) $8 /$ & 7.6 & 7.8 & 7.5 & 7.7 & 5.9 & 4.8 & 6.2 & 6.2 & 6.2 & 6.2 & 6.2 & \\
\hline Average real interest rate (nominal rate minus change in GDP deflator, in percent) & 3.1 & 0.9 & 3.0 & 1.0 & 1.6 & 1.1 & 3.6 & 2.7 & 2.7 & 2.9 & 2.7 & \\
\hline Nominal appreciation (increase in US dollar value of local currency, in percent) & 4.8 & -1.6 & -1.0 & -21.1 & 5.9 & 0.0 & -1.7 & -1.3 & -1.2 & -1.1 & -0.9 & \\
\hline Inflation rate (GDP deflator, in percent) & 4.5 & $\begin{array}{r}-1.9 \\
6.9\end{array}$ & 4.5 & 6.6 & 4.3 & 3.7 & 2.6 & 3.5 & 3.4 & 3.3 & 3.4 & \\
\hline Grow th of real primary spending (deflated by GDP deflator, in percent) & 12.3 & 7.1 & 5.4 & 9.0 & 6.3 & 0.9 & -0.4 & 1.5 & 4.1 & 2.4 & 2.2 & \\
\hline Primary deficit & -1.5 & -1.7 & $\begin{array}{c}0.4 \\
-1.4\end{array}$ & $\begin{array}{c}3.0 \\
-1.3\end{array}$ & 2.3 & 1.6 & 0.6 & -0.1 & -0.1 & $\begin{array}{c}2.4 \\
-0.2\end{array}$ & -0.3 & \\
\hline
\end{tabular}

1/ Public sector includes federal government, Pemex, other public companies, develoment banks, Pidiregas, IPAB, debtor's program, and FARAC

$2 /$ Derived as $[(r-\pi(1+g)-g+\alpha \varepsilon(1+r)] /(1+g+\pi+g \pi))$ times previous period debt ratio, $w$ ith $r=$ interest rate; $\pi=$ grow th rate of GDP deflator; $g=$ real GDP grow th rate; $\alpha=$ share of foreign-currency $2 /$ Derived as $((r-\pi(1+g)-g+\alpha \varepsilon(1+r))(1+g+\pi+g \pi)$ ) times previous period debt ratio, $w$ ith $r=$ interest rate, $\pi=$ grow th rate
denominated debt; and $\varepsilon=$ nominal exchange rate depreciation (measured by increase in local currency value of U.S. dollar)

$3 /$ The real interest rate contribution is derived from the denominator in footnote $2 /$ as $r-\pi(1+g)$ and the real grow th contribution as -g

$4 /$ The exchange rate contribution is derived from the numerator in footnote $2 /$ as $\alpha s(1+r)$.

5/ For projections, this line includes exchange rate changes.

6/ Defined as public sector deficit, plus amortization of medium and long-term public sector debt, plus short-term debt at end of previous period.

7/ The key variables include real GDP grow th; real interest rate; and primary balance in percent of GDP.

/ Derived as nominal interest expenditure divided by previous period debt stock.

9/ Assumes that key variables (real GDP grow th, real interest rate, and other identified debt-creating flows) remain at the level of the last projection year.

\section{CInternational Monetary Fund. Not for Redistribution}


Table 7. Mexico: Indicators of Fund Credit 2010-2016

\begin{tabular}{|c|c|c|c|c|c|c|c|}
\hline & \multicolumn{7}{|c|}{ Projections } \\
\hline & 2010 & 2011 & 2012 & 2013 & 2014 & 2015 & 2016 \\
\hline \multicolumn{8}{|l|}{ Stocks from prospective drawings $1 /$} \\
\hline Fund credit in millions SDR & 0 & 47,292 & 47,292 & 47,292 & 29,558 & 5,912 & 0 \\
\hline In percent of quota & 0 & 1,500 & 1,500 & 1,500 & 938 & 0 & 0 \\
\hline In percent of GDP & 0 & 7 & 7 & 6 & 4 & 1 & 0 \\
\hline In percent of exports of goods and services & 0 & 22 & 21 & 19 & 11 & 2 & 0 \\
\hline In percent of gross reserves & 0 & 36 & 34 & 33 & 22 & 5 & 0 \\
\hline \multicolumn{8}{|l|}{ Flows from prospective drawings $2 /$} \\
\hline Charges (Millions SDR) & 0 & 1,364 & 1,396 & 1,395 & 1,461 & 507 & 16 \\
\hline Debt Service due on GRA credit (Millions SDR) & 0 & 1,364 & 1,396 & 1,395 & 19,195 & 24,207 & 5,297 \\
\hline In percent of quota & 0 & 43 & 44 & 44 & 609 & 768 & 168 \\
\hline In percent of GDP & 0 & 0.2 & 0.2 & 0.2 & 2.4 & 2.8 & 0.6 \\
\hline In percent of exports of goods and services & 0 & 0.6 & 0.6 & 0.6 & 7.1 & 8.4 & 1.7 \\
\hline In percent of gross reserves & 0 & 1 & 1 & 1 & 14 & 21 & 5 \\
\hline \multicolumn{8}{|l|}{ Memo Item: } \\
\hline Total External Debt (percent of GDP) & 24.2 & 31.6 & 30.8 & 29.9 & 26.9 & 23.3 & 21.9 \\
\hline
\end{tabular}

Sources: IMF Finance Department; Mexican authorities, and Fund staff estimates

1/ End of period. Assumes full draw ings under the FCL upon approval of the review. The Mexican authorities have expressed their intention to treat the arrangement as precautionary. At an SDR/US\$ rate of 0.642229 as of November 15, 2010.

2/ Based on the rate of charge as of December 16, 2010. Includes surcharges under the system currently in force and service charges. 
Table 8. Mexico: Financial Soundness Indicators

\begin{tabular}{|c|c|c|c|c|}
\hline & 2007 & 2008 & 2009 & Sep-10 \\
\hline \multicolumn{5}{|l|}{ (in percent) } \\
\hline \multicolumn{5}{|l|}{ Capital Adequacy } \\
\hline Regulatory capital to risk-weighted assets & 15.9 & 15.3 & 16.5 & 17.1 \\
\hline Regulatory Tier 1 capital to risk-weighted assets & 14.7 & 13.3 & 14.6 & 15.2 \\
\hline Capital to assets & 13.8 & 9.2 & 10.1 & 10.5 \\
\hline Gross asset position in financial derivatives to capital & 36.1 & 47.1 & 57.6 & 73.0 \\
\hline Gross liability position in financial derivatives to capital & 35.0 & 47.7 & 59.5 & 73.6 \\
\hline \multicolumn{5}{|l|}{ Asset Quality } \\
\hline Nonperforming loans to total gross loans & 2.7 & 3.2 & 3.1 & 2.2 \\
\hline Provisions to Nonperforming loans & 168.9 & 161.2 & 173.8 & 196.4 \\
\hline \multicolumn{5}{|l|}{ Earnings and Profitability } \\
\hline Return on assets & 2.7 & 1.1 & 1.5 & 1.9 \\
\hline Return on equity & 19.9 & 8.9 & 15.2 & 17.8 \\
\hline Personnel expenses to noninterest expenses & 88.0 & 87.7 & 87.1 & 94.5 \\
\hline \multicolumn{5}{|l|}{ Liquidity } \\
\hline Liquid assets to total assets & 50.4 & 40.4 & 42.7 & 42.1 \\
\hline Liquid assets to short-term liabilities & 64.2 & 56.1 & 57.7 & 58.1 \\
\hline Customer deposits to total (noninterbank) loans & 95.8 & 99.6 & 92.7 & 85.0 \\
\hline
\end{tabular}

Source: CNBV. 
Table 9 : Comparison of Access in Fund Arrangements

\begin{tabular}{|c|c|c|c|c|c|}
\hline & \multirow{3}{*}{$\begin{array}{c}\text { Proposed } \\
\text { Arrangement }\end{array}$} & \multicolumn{4}{|c|}{ High-Access Cases 1/ } \\
\hline & & \multirow{2}{*}{$\begin{array}{l}\text { Proposed } \\
\text { Arrangement } \\
\text { (Percentile) }\end{array}$} & $\begin{array}{c}\text { 20th } \\
\text { Percentile } \\
\end{array}$ & $\begin{array}{c}\text { 80th } \\
\text { Percentile } \\
\end{array}$ & Median \\
\hline & & & \multicolumn{2}{|c|}{ (Ratio) } & \\
\hline \multicolumn{6}{|l|}{ Access } \\
\hline In millions of SDRs & 47,292 & 100 & 1,449 & 13,424 & 6,662 \\
\hline \multicolumn{6}{|l|}{ Total access in percent of: $2 /$} \\
\hline Actual quota & 1,500 & 94 & 300 & 1,000 & 560 \\
\hline Gross domestic product & 5 & 38 & 2.9 & 9.0 & 6 \\
\hline \multicolumn{6}{|l|}{ Total debt stock } \\
\hline Of which: Public & 49 & 90 & 9 & 33 & 12 \\
\hline
\end{tabular}

Source: Executive Board documents, MONA database, and Fund staff estimates.

1/ High access cases include available data at approval and on augmentation for all the requests to the Board since 1997 which involved the use of the exceptional circumstances clause or SRF resources. Exceptional access augmentations are counted as separate observations. For the purpose of measuring access as a ratio $2 /$ The data used to calculate ratios is the actual value for the year prior to approval for public debt, and the projection at the time of program approval for the year in which the program was approved for all other 
Table 10. FCL for Mexico-Impact on GRA Finances

(In SDR millions, unless otherwise indicated)

As of $12 / 02 / 2010$

\section{Liquidity measures}

Current one-year Forward Commitment Capacity (FCC) 1/

FCC including the proposed EFF for Ireland

Net impact on FCC on approval of FCL

15,764

FCC including the proposed EFF for Ireland and FCL for Mexico

\section{Prudential measures, assuming full FCL drawing}

Fund credit to Mexico

In percent of total GRA credit outstanding 2/

In percent of current precautionary balances

Fund credit outstanding to five largest debtors

In percent of total GRA credit outstanding, before approval

In percent of total GRA credit outstanding, upon approval of the FCL 2/

\section{Memorandum items}

Current precautionary balances (end-April 2010)

Total FCL commitments, including proposed FCL 3/

Quota of FTP members with actual and proposed FCLs, in percent of total quota of FTP memb€

Sources: Finance Department.

1/ The FCC measures the Fund's capacity to make new credit commitments over the next 12 months. It includes the liquidity effects of resources made available under borrowing and note purchase agreements.

2/ Based on current Fund credit outstanding plus full drawings under the proposed FCL.

3/ Excluding Mexico's existing FCL. 
Dear Mr. Strauss-Kahn,

The global financial crisis presented Mexico with significant challenges, exacerbated by the AH1N1 episode in the second quarter of 2009; in spite of this, economic stability has been maintained and recovery is solidly underway. As noted in the 2010 Article IV consultation, this has owed much to Mexico's strong policy framework, the progress made toward improving the private and public sector balance sheets over recent years, and targeted and well-calibrated policy responses during the crisis. The two Flexible Credit Line (FCL) arrangements with the Fund, as well as the swap line with the U.S. Federal Reserve, also provided important support to our economic strategy and helped sustain confidence.

While we expect the economic recovery in Mexico to continue, downside risks to the global outlook have risen in recent months - as discussed in the latest World Economic Outlook and Global Financial Stability Report, and suggested by recent market indicatorsincreasing global uncertainty. Against this background, and in accordance with the decision reached by the Exchange Commission on December 3rd, we would like the Fund to approve a successor 24-month FCL arrangement for Mexico in the amount of SDR 47,292 million (1,500 percent of quota). The enhancement in duration and access of the FCL facilityfeatures made possible by the recent Fund facilities reform - has substantially increased the reserve like nature of FCL resources. As such, we believe that a new FCL arrangement, which we again intend to treat as precautionary, will play an even stronger role in insuring against tail risk events and supporting public confidence.

In the period ahead, our policy priorities are to support the recovery; maintain economic and financial stability; and continue to fortify the basis for strong and sustainable medium-term growth. On the fiscal side, policy will remain guided by the balanced budget rule and the medium-term budgetary framework, and the aim to ensure that public debt as a share of GDP is firmly on a downward path. We have followed the strategy for public finances that was described in 2009 in our Economic Policy Guidelines for 2010 which implied an important fiscal effort to offset the revenue losses from a decline in oil production while at the same time withdrawing gradually the fiscal stimulus required in 2009 to cushion the downturn, thus preserving room for priority spending and providing assurances on sustainability. These policy measures included a significant tax reform in 2010 complemented by the planned spending restraint envisaged in the 2011 budget, with the aim of returning the fiscal position targeted under our rule to balance by $2012^{1}$

\footnotetext{
${ }^{1}$ See

http://www.apartados.hacienda.gob.mx/presupuesto/temas/ppef/2011/temas/expo_motivos/criterios/cgpe 2011. pdf
} 
In addition, we have again suspended the cap on savings in the stabilization funds in 2011 to facilitate a faster rebuilding of fiscal buffers. We are also continuing to improve expenditure management, reduce fossil fuel subsidies and further strengthen tax administration, in order to preserve space to finance priority public investment and social spending.

On the monetary side, our policy continues to be underpinned by the inflation targeting regime, which has effectively anchored medium-term inflation expectations. Despite a temporary rise in early 2010, inflation has resumed its downward trend. Correspondingly, and - given also the still important economic slack—policy interest rates have been maintained constant, and inflation is expected to converge to the 3 percent target (with a variability interval of -/+ 1 percent) by mid-2011, about one semester in advance of the horizon set out in our previous policy publications. ${ }^{2}$ Meanwhile, as part of our continuing efforts to strengthen policy communications, we plan to publish the minutes of the policy meetings and present the central bank's macroeconomic projections in a richer context beginning in 2011 .

Consistent with our monetary framework, we remain committed to maintaining the flexible exchange rate regime, which proved to be an important shock absorber during the crisis. With Mexico's reserve coverage being lower than those observed in several of its emerging market peers relative to several indicators, we have continued to augment our international reserves by retaining the foreign exchange receipts from Pemex and the Federal Government, as well as through a rules-based mechanism introduced in March, in a manner fully consistent with our floating exchange rate regime. ${ }^{3}$

Aided by a strong regulatory framework, the banking sector remains well-capitalized with a healthy liquidity profile, and is resilient to a range of stress scenarios (as discussed in Banxico's latest Financial Stability Report). ${ }^{4}$ Since March, we have continued to take steps to further improve our financial regulation and supervision, including through preparing for the pending Basel III implementation. These and other strengths of the bank regulatory framework in Mexico were recognized by the FSB in the course of their peer review of

\footnotetext{
${ }^{2}$ See http://www.banxico.org.mx/publicaciones-y-discursos/publicaciones/informes-periodicos/trimestralinflacion/\%7B9CC0BD73-0AC2-B6EE-7D46-5A1424F0EE07\%7D.pdf

${ }^{3}$ See

http://www.hacienda.gob.mx/SALAPRENSA/doc_comunicados_prensa/2010/febrero/shcp banxico anuncio_c omision_cambios 22feb10.pdf

${ }^{4}$ See http://www.banxico.org.mx/publicaciones-y-discursos/publicaciones/informes-periodicos/reportesf/\%7BDC37ABCB-26F0-020D-145B-5CF397D62E68\%7D.pdf
} 
Mexico, the first for any member of the G-20. In addition, we have recently set up a highlevel cross-agency financial stability council to strengthen systemic risk monitoring and coordinate policy and regulatory responses.

To help expand the economy's medium-term growth potential, a key developmental objective going forward, various structural reform initiatives have been advanced. Earlier this year, concrete proposals aimed at increasing labor market flexibility and improving antitrust enforcement were submitted to the Congress for discussion. Other ongoing key structural measures include increasing competition in the telecommunications sector, a phasing in of a substantial reduction in import tariffs to promote trade, and efforts to lower the regulatory burden faced by businesses.

In sum, as Executive Directors acknowledged in the 2010 Article IV consultation discussion, Mexico's policy framework remains strong, and economic policies have responded in a timely and appropriate fashion in managing the impact of the global crisis and subsequently supporting the recovery. We will continue to react as needed to any future shocks that may arise.

Sincerely yours,

$$
/ \mathrm{s} /
$$

Ernesto Javier Cordero Arroyo

Minister of Finance and Public Credit
$/ \mathrm{s} /$

Agustín Guillermo Carstens Carstens Governor of Banco de México 


\title{
INTERNATIONAL MONETARY FUND
}

\section{Mexico-Assessment of the Impact of the Proposed Flexible Credit Line Arrangement on the Fund's Finances and Liquidity Position}

\author{
Prepared by the Finance and Strategy, Policy and Review Departments
}

(In consultation with other Departments)

Approved by Andrew Tweedie and Aasim Husain

December 28, 2010

\begin{abstract}
1. This note assesses the impact of the proposed Flexible Credit Line (FCL) arrangement for Mexico on the Fund's finances and liquidity position, in accordance with the policy on FCL arrangements. ${ }^{1}$ The proposed arrangement would cover a 24-month period and access would be in an amount of SDR 47.292 billion (1,500 percent of quota). It would succeed the existing FCL arrangement which would be cancelled upon approval of the proposed arrangement. The full amount of access proposed would be available throughout the arrangement period, in one or multiple purchases. ${ }^{2}$ The authorities intend to treat the arrangement as precautionary.
\end{abstract}

\section{BACKGROUND}

2. Against the backdrop of a global economic and financial crisis, a one-year FCL arrangement equivalent to SDR 31.5 billion was approved on April 17, 2009 that the authorities treated as precautionary. This arrangement was succeeded by another FCL arrangement on identical terms approved on March 25, 2010. While Mexico has faced significant challenges in recent years, macroeconomic stability has been supported by the authorities' strong and timely policy response to the global crisis, and no drawings have been made under the previous and the existing FCL arrangements. As discussed in Annex I, Mexico has a history of strong performance under earlier Fund arrangements and an exemplary record of meeting its obligations to the Fund.

3. Total external and public debt levels are moderate. External debt, which was below 20 percent of GDP in the years preceding the recent crisis, increased in 2009 to about

\footnotetext{
${ }^{1}$ See GRA Lending Toolkit and Conditionality-Reform Proposals (3/13/09) and Flexible Credit Line (FCL) Arrangements, Decision No.14283-(09/29), adopted March 24, 2009.

${ }^{2}$ If the full amount is not drawn in the first year of the arrangement, subsequent purchases can only be made following completion of a review of Mexico's continued qualification for the FCL arrangement.
} 
24 percent of GDP largely as a result of the depreciation of the peso and the significant contraction in real GDP. As the economy recovers from the recent decline in output, external debt is projected to decline gradually over the medium term. Short-term debt on a residual maturity basis accounts for less than 25 percent of total external debt. Gross public debt that had stabilized at just under 40 percent of GDP before the crisis, is projected to increase to slightly above 45 percent of GDP by end-2011 before starting to decline again in the subsequent years. Public external debt is estimated at about 10 percent of GDP at end 2010. Sustainability analyses show both external and public debt remaining manageable under a range of scenarios, with no significant contingent liabilities incurred during the crisis.

4. The proposed FCL arrangement would represent the largest individual commitment of Fund resources to date and could result in a record high credit exposure. ${ }^{3}$ The proposed FCL arrangement is by 50 percent higher than the existing FCL arrangement for Mexico, which is already the largest General Resources Account (GRA) arrangement in the Fund's history. If the full amount available under the FCL arrangement were drawn, Mexico's outstanding use of GRA resources would reach SDR 47.3 billion, more than twice the Fund's largest credit exposure to date.

\section{If the full amount available under the proposed FCL arrangement were disbursed in 2011:}

- Mexico's external debt would remain moderate, with Fund credit representing a significant part of this debt: total external debt would rise to about 32 percent of GDP initially, and public external debt would rise close to 17 percent of GDP, with Fund credit representing 7 percent of GDP (Table 1). At its peak, Mexico's outstanding use of GRA resources would account for 22 percent of total external debt, 43 percent of public external debt, and 36 percent of gross international reserves.

- External debt service would increase in the medium-term, but remain manageable under staff's medium-term macro projections. Mexico's projected debt service to the Fund would peak in 2015 at about SDR 24.2 billion, or about 2.8 percent of GDP. ${ }^{4}$ In terms of exports of goods and services, external debt service to the Fund would peak at about 8.4 percent, accounting for almost 60 percent of total public external debt service, which would increase to just over 14 percent of exports of goods and services.

\footnotetext{
${ }^{3}$ The largest GRA credit exposure has been SDR 23.359 billion to Brazil in 2003.

${ }^{4}$ The figures on debt service used in this report are calculated assuming that the full amount available under the arrangement is purchased upon approval of the arrangement, and that all repurchases are made as scheduled.
} 
Table 1. Mexico: Capacity to Repay Indicators 1/

\begin{tabular}{|c|c|c|c|c|c|c|c|}
\hline & 2010 & 2011 & 2012 & 2013 & 2014 & 2015 & 2016 \\
\hline \multicolumn{8}{|c|}{ Exposure and Repayments (In SDR millions) } \\
\hline $\begin{array}{l}\text { GRA credit to Mexico } \\
\text { (In percent of quota) }\end{array}$ & $(0 . \overline{0})$ & $\begin{array}{l}47,292.0 \\
(1,500.0)\end{array}$ & $\begin{array}{l}47,292.0 \\
(1,500.0)\end{array}$ & $\begin{array}{l}47,292.0 \\
(1,500.0)\end{array}$ & $\begin{array}{r}29,557.5 \\
(937.5)\end{array}$ & $\begin{array}{l}5,911.5 \\
(187.5)\end{array}$ & $(0.0)$ \\
\hline Charges due on GRA credit 2/ & -- & $1,364.2$ & $1,395.9$ & $1,394.7$ & $1,460.8$ & 560.5 & 15.5 \\
\hline Debt service due on GRA credit 2/ & -- & $1,364.2$ & $1,395.9$ & $1,394.7$ & $19,195.3$ & $24,206.5$ & $5,927.0$ \\
\hline \multicolumn{8}{|l|}{ Debt and Debt Service Ratios 3/ } \\
\hline \multicolumn{8}{|l|}{ In percent of GDP } \\
\hline Total external debt & 24.2 & 31.6 & 30.8 & 29.9 & 26.9 & 23.3 & 21.9 \\
\hline Public external debt & 10.4 & 16.9 & 15.6 & 14.5 & 11.4 & 7.8 & 6.7 \\
\hline GRA credit to Mexico & -- & 7.1 & 6.6 & 6.2 & 3.6 & 0.7 & -- \\
\hline Total external debt service & 6.1 & 6.0 & 6.0 & 6.1 & 8.5 & 9.0 & 6.6 \\
\hline Public external debt service & 1.0 & 2.1 & 2.6 & 2.4 & 4.4 & 4.7 & 2.4 \\
\hline Debt service due on GRA credit & -- & 0.2 & 0.2 & 0.2 & 2.4 & 2.8 & 0.6 \\
\hline \multicolumn{8}{|l|}{ In percent of Gross International Reserves } \\
\hline Total external debt & 197.4 & 159.4 & 158.3 & 157.2 & 163.3 & 173.6 & 171.9 \\
\hline Public external debt & 85.1 & 85.1 & 80.3 & 76.3 & 69.0 & 58.4 & 52.6 \\
\hline GRA credit to Mexico & -- & 35.7 & 34.0 & 32.5 & 22.0 & 5.1 & -- \\
\hline \multicolumn{8}{|c|}{ In percent of Exports of Goods and Services } \\
\hline Total external debt service & 19.2 & 18.9 & 18.6 & 18.6 & 25.6 & 27.1 & 19.2 \\
\hline Public external debt service & 3.1 & 6.6 & 8.1 & 7.4 & 13.3 & 14.3 & 7.0 \\
\hline Debt service due on GRA credit & -- & 0.6 & 0.6 & 0.6 & 7.1 & 8.4 & 1.9 \\
\hline \multicolumn{8}{|l|}{ In percent of Total External Debt } \\
\hline GRA credit to Mexico & -- & 22.4 & 21.5 & 20.7 & 13.5 & 2.9 & -- \\
\hline \multicolumn{8}{|l|}{ In percent of Public External Debt } \\
\hline GRA credit to Mexico & -- & 41.9 & 42.4 & 42.6 & 31.9 & 8.7 & -- \\
\hline
\end{tabular}

Sources: Mexican authorities, Finance Department, World Economic Outlook, and IMF staff estimates.

1/ Assumes full drawings under the FCL upon approval. The Mexican authorities have expressed their intention to treat the arrangement as precautionary, as balance of payments pressures have not materialized.

2/ Based on the rate of charge as of December 16, 2010. Includes surcharges under the system currently in force and service charges.

3 / Staff projections for external debt, GDP, gross international reserves, and exports of goods and services, adjusted for the impact

of the assumed FCL drawing.

6. The impact of the proposed arrangement on the Fund liquidity, and on Fund exposure if disbursed, would be very large:

The combination of the cancelation of the current FCL and the approval of the proposed arrangement would reduce the Fund's one-year forward commitment capacity (FCC) by about 12 percent on a net basis. The liquidity impact would be a reduction in the FCC by SDR 15.8 billion to SDR 116.5 billion. While this level of liquidity remains comfortable by historical standards, the capacity of the Fund to make new commitments could deteriorate rapidly if other members with large financing needs request support. In this regard, the continued availability of supplementary resources under the bilateral borrowing and note purchase agreements, 
as well as early effectiveness of the expanded NAB are key for maintaining the adequacy of the Fund's resources. ${ }^{5}$

- If the resources available under the FCL arrangement were fully drawn, GRA credit to Mexico as a share of total GRA credit would be about 47 percent. As a result, the concentration of Fund credit among the top five users of Fund resources would increase to about 80 percent, from 72 percent currently.

- $\quad$ Potential GRA exposure to Mexico would be very large in relation to the current level of the Fund's precautionary balances. If the resources available under the arrangement were fully drawn, Fund credit to Mexico would be equivalent to some $6 \frac{1}{2}$ times the Fund's current precautionary balances.

\section{Table 2. FCL Arrangement for Mexico-Impact on GRA Finances}

(In SDR millions, unless otherwise indicated)

\begin{tabular}{lr}
\hline & As of 12/20/2010 \\
\hline Liquidity measures & 132,236 \\
Current one-year Forward Commitment Capacity (FCC) 1/ & 15,764 \\
Impact on FCC on approval of FCL (net) 2/ & 47.5 \\
Prudential measures, assuming full FCL drawing & 646.1 \\
Fund credit to Mexico & 72.4 \\
$\quad$ In percent of total GRA credit outstanding 3/ & 80.3 \\
$\quad$ In percent of current precautionary balances & \\
Fund credit outstanding to five largest debtors & \\
$\quad$ In percent of total GRA credit outstanding, before approval & 7,320 \\
$\quad$ In percent of total GRA credit outstanding, upon approval of the FCL $3 /$ & 63,304 \\
Memorandum items & 2.9 \\
Current precautionary balances (FY 2010) 4/ & \\
Total FCL commitments, including proposed FCL 5/ & \\
Quota of FTP members with actual and proposed FCLs, in percent of total quota of FTP members & \\
\hline
\end{tabular}

Sources: Finance Department.

1/ The FCC measures the Fund's capacity to make new credit commitments over the next 12 months. It includes the liquidity effects of resources made available under borrowing and note purchase agreements.

2/ Takes into account the cancellation of the current FCL. The gross liquidity impact of the proposed FCL would be SDR 47.292 billion.

3/ Based on current Fund credit outstanding plus full drawings under the proposed FCL.

4/ Precautionary balances exclude amounts in Special Reserves attributable to profits on gold sales in FY2010.

5/ Excluding Mexico's existing FCL.

\section{Assessment}

7. The proposed record high commitment has a very substantial, but manageable impact on the Fund's liquidity. The current liquidity position is sufficiently strong to

\footnotetext{
${ }^{5}$ An update on the Fund's liquidity position reflecting developments since the last review (see The Fund's Liquidity Position - Review and Outlook, www.imf.org, 10/4/2010) will be issued separately.
} 
accommodate the liquidity impact of the proposed arrangement, especially since the cancellation of Mexico's existing FCL arrangement would partially offset the initial effect from the proposed new FCL arrangement. Nevertheless, in view of the significant uncertainty surrounding the recovery from the global crisis and the likelihood of continuing strong demand for Fund financing, a close monitoring of the liquidity position is warranted.

\section{Mexico intends to treat the FCL arrangement as precautionary, but if drawn,} this would become the Fund's largest single credit exposure. Mexico's overall external debt and debt service ratios are expected to remain moderate even with a drawing under the arrangement. Hence, given Mexico's sustained track record of implementing very strong policies, including during the global financial crisis, and commitment to maintaining such policies in future, Mexico's capacity to repay is projected to remain strong. Nonetheless, the scale of the Fund's potential exposure to Mexico-in conjunction with the recent increase in lending to other members and the prospects for further credit expansion under already existing or possible new Fund arrangements - underscores the need to strengthen the Fund's precautionary balances. 


\section{ANNEX I. MEXICO: HiSTORY OF IMF ARRANGEMENTS}

This annex provides a brief overview of Mexico's Fund arrangements from 1983 to present.

Prior to the one-year FCL arrangements approved in April 2009 and March 2010, Mexico had several Fund arrangements in the 1980s and 1990s. It fully repaid its remaining outstanding credit in 2000 (Table I.1). Mexico has an exemplary track record of meeting its obligations to the Fund.

From 1983 to 2000, Mexico had two arrangements under the Extended Fund Facility (EFF) and three Stand-By Arrangements (SBAs). Below is a brief description of the two most recent SBAs:

- In February 1995, the Fund approved an SBA equivalent to SDR 12.1 billion (688 percent of quota) to support Mexico's adjustment program to deal with a major financial and economic crisis. Under that arrangement, Mexico made purchases totaling SDR 8.8 billion, and its outstanding credit peaked at SDR 10.6 billion (607 percent of quota) at end-1995 (Figure I.1). After regaining access to international capital markets in the second half of 1996, Mexico made sizable advance repurchases.

- In July 1999, an SBA equivalent to SDR 3.1 billion was approved as the recovery in economic performance was disrupted by unsettled conditions in international capital markets. Solid performance under the program supported by this SBA allowed Mexico to fully repay all its outstanding obligations to the Fund through a series of advance repurchases before the SBA expired in November 2000.

A one-year FCL arrangement equivalent to SDR 31.5 billion was approved on April 17, 2009 to support Mexico's economic policies and bolster confidence during the crisis. A successor FCL arrangement on identical terms was approved on March 25, 2010. No drawings have been made under the two FCL arrangements. 
Table I.1. Mexico: IMF Financial Arrangements, 1983-2010

(In millions of SDR)

\begin{tabular}{|c|c|c|c|c|c|c|c|c|}
\hline Year & $\begin{array}{c}\text { Type of } \\
\text { Arrangement }\end{array}$ & $\begin{array}{c}\text { Date of } \\
\text { Arrangement }\end{array}$ & $\begin{array}{l}\text { Date of Expiration } \\
\text { or Canellation }\end{array}$ & $\begin{array}{l}\text { Amount of New } \\
\text { Arrangement }\end{array}$ & $\begin{array}{l}\text { Amount } \\
\text { Drawn }\end{array}$ & Purchases & Repurchases & Fund Exposure 1/ \\
\hline 1983 & EFF & 1-Jan-83 & 31-Dec-85 & $3,410.6$ & $2,502.7$ & $1,003.1$ & 0.0 & $1,203.8$ \\
\hline 1984 & & & & & & $1,203.8$ & 0.0 & $2,407.5$ \\
\hline 1985 & & & & & & 295.8 & 0.0 & $2,703.3$ \\
\hline 1986 & SBA & 19-Nov-86 & 1-Apr-88 & $1,400.0$ & $1,400.0$ & $741.4 \quad 2 /$ & 125.4 & $3,319.3$ \\
\hline 1987 & & & & & & 600.0 & 280.0 & $3,639.3$ \\
\hline 1988 & & & & & & 350.0 & 419.0 & $3,570.3$ \\
\hline 1989 & EFF & 26-May-89 & 25-May-93 & $3,729.6$ & $3,263.4$ & $943.0 \quad 3 /$ & 639.6 & $3,873.6$ \\
\hline 1990 & & & & & & $1,608.4$ & 877.1 & $4,604.9$ \\
\hline 1991 & & & & & & 932.4 & 807.4 & $4,729.9$ \\
\hline 1992 & & & & & & 233.1 & 636.1 & $4,327.0$ \\
\hline 1993 & & & & & & 0.0 & 841.7 & $3,485.2$ \\
\hline 1994 & & & & & & 0.0 & 841.0 & $2,644.2$ \\
\hline 1995 & SBA & 1-Feb-95 & 15-Feb-97 & $12,070.2$ & $8,758.0$ & $8,758.0$ & 754.1 & $10,648.1$ \\
\hline 1996 & & & & & & 0.0 & $1,413.6$ & $9,234.5$ \\
\hline 1997 & & & & & & 0.0 & $2,499.2$ & $6,735.2$ \\
\hline 1998 & & & & & & 0.0 & 783.7 & $5,951.5$ \\
\hline 1999 & SBA & 07-Jul-1999 & $30-N o v-2000$ & $3,103.0$ & $1,939.5$ & $1,034.4$ & $3,726.7$ & $3,259.2$ \\
\hline 2000 & & & & & & 905.1 & $4,164.3$ & 0.0 \\
\hline \multicolumn{9}{|l|}{$\cdots$} \\
\hline 2009 & $\mathrm{FCL}$ & 17-Apr-2009 & 16-Apr-2010 & $31,528.0$ & 0.0 & 0.0 & 0.0 & 0.0 \\
\hline 2010 & FCL & 25-Mar-2010 & 24-Mar-2011 & $31,528.0$ & 0.0 & 0.0 & 0.0 & 0.0 \\
\hline
\end{tabular}

Source: Finance Department.

$1 /$ As of end-December.

2/ Includes a first credit tranche purchase of SDR 291.4 million.

3 / Includes a purchase of SDR 453.5 million under the Compensatory Financing Facility.

Figure I.1. Mexico: IMF Credit Outstanding, 1982-2000

(In millions of SDRs)

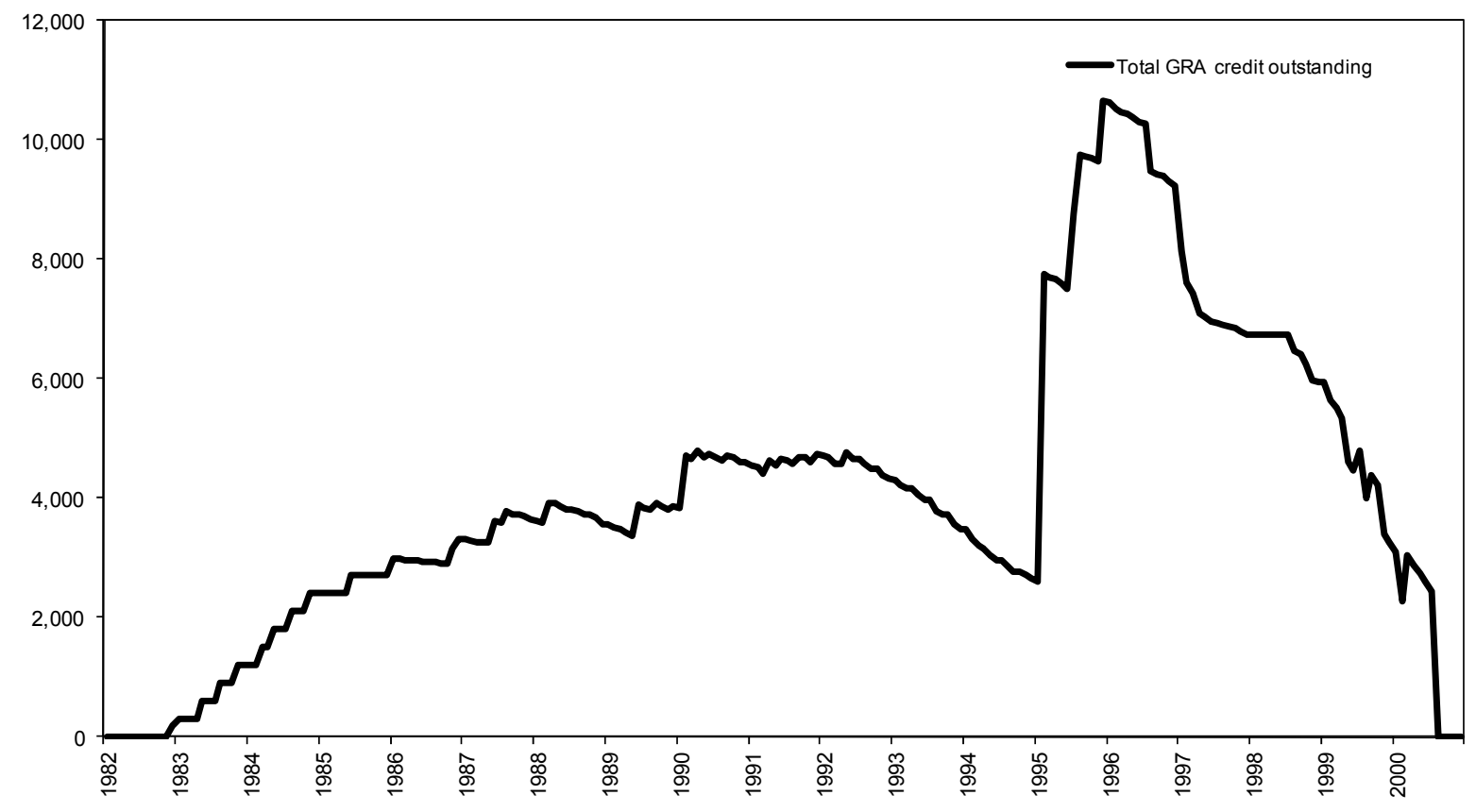

Source: Finance Department. 
January 10, 2011

\section{IMF Executive Board Approves New Two-Year US\$72 billion Flexible Credit Line Arrangement with Mexico}

The Executive Board of the International Monetary Fund (IMF) today approved a successor two-year arrangement for Mexico under the Flexible Credit Line (FCL) in an amount equivalent to SDR 47.292 billion (about US\$72 billion ${ }^{1}$ ). The Mexican authorities stated they intend to treat the arrangement as precautionary and do not intend to draw on the line.

Mexico's first FCL was approved on April 17, 2009 (see Press Release No. 09/130), and was renewed in March 25, 2010 (see Press Release No. 10/114).

Following the Executive Board discussion of Mexico, Mr. John Lipsky, First Deputy Managing Director and Acting Chairman of the Board, made the following statement:

"Mexico has very strong economic fundamentals and a robust policy framework. Major progress has been made over the years toward strengthening public and private sector balance sheets and reinforcing the resilience of the financial sector. Policy credibility and economic stability have been underpinned by a comprehensive rules-based policy setting, including the balanced budget rule, the inflation targeting framework, and the flexible exchange rate regime.

"These strengths have facilitated the maintenance of orderly economic conditions in Mexico, even amidst the substantial external volatility during the global crisis, supported by the authorities' prompt and well-calibrated policy responses. The arrangement of contingent financing with the IMF through the Flexible Credit Line has helped maintain confidence.

"Since mid-2009, Mexico has been experiencing a robust cyclical recovery. The authorities have continued to undertake important initiatives - including the 2010 tax reform, the establishment of a high-level council to improve systemic risk monitoring in the financial sector, and seeking to advance structural reforms, including those of the labor market and the

${ }^{1}$ Amount based on the Special Drawing Right (SDR) quote of January 10, 2010 of 1 USD = SDR 0.65632 
competition framework - as part of their long-standing drive to further bolster medium-term prospects and strengthen the policy framework.

"However, important risks to the global economic outlook remain, particularly from pressures on global investor confidence and capital flows, which pose continuing challenges for emerging markets like Mexico. At the authorities' request, the Executive Board today approved a new arrangement under the IMF's FCL as a successor to the previous arrangement approved in March 2010. As before, the authorities intend to treat the arrangement as precautionary. The augmented duration and size of this successor FCL-new features made possible by the recent IMF facilities reform-will allow the FCL to play an even stronger role in insuring Mexico against external risks while continuing to support the authorities' overall macroeconomic strategy," Mr. Lipsky said.

The FCL was established on March 24, 2009 for countries with very strong fundamentals, policies, and track records of policy implementation and is particularly useful for crisis prevention purposes. FCL arrangements are approved for countries meeting pre-set qualification criteria (see Press Release No. 09/85).

The FCL was further enhanced with reforms approved in August 30, 2010 (see Press Release No. 10/321). The duration of the line was expanded from one year to up to two years (with an interim review of continued qualification after one year) and the removal of the cap on access to resources to 1000 percent of a country's quota. The repayment period is between three and five years. Access is determined on a case-by-case basis, and can be made available in a single up-front disbursement rather than phased. Disbursements under the FCL are not conditioned on implementation of specific policy targets or meeting quantitative criteria. There is flexibility to either draw on the credit line at the time it is approved, or treat it as precautionary.

Mexico is a member of the IMF since 1945 and has a quota of SDR 3,152 million (about US\$4.8 billion).To read the staff report and other documents related to the approval of Mexico's Flexible Credit Line, please see http://www.imf.org/external/pubs/ft/scr/2011/cr1111.pdf 